\title{
Case Study of Municipal Waste and Its Reliance on Reverse Logistics in European Countries
}

\author{
Olga Lingaitienè (D), Aurelija Burinskienè * and Vida Davidavičienè (D) \\ Faculty of Business Management, Vilnius Gediminas Technical University, LT-10223 Vilnius, Lithuania; \\ olga.lingaitiene@vilniustech.lt (O.L.); vida.davidaviciene@vilniustech.lt (V.D.) \\ * Correspondence: aurelija.burinskiene@vilniustech.lt
}

check for

updates

Citation: Lingaitienè, O.; Burinskienè, A.; Davidavičienè, V. Case Study of Municipal Waste and Its Reliance on Reverse Logistics in European Countries. Sustainability 2022, 14, 1809. https://doi.org/ $10.3390 /$ su14031809

Academic Editors: Sunil Kumar, Pooja Sharma and Deblina Dutta

Received: 2 December 2021

Accepted: 29 January 2022

Published: 5 February 2022

Publisher's Note: MDPI stays neutral with regard to jurisdictional claims in published maps and institutional affiliations.

Copyright: (c) 2022 by the authors. Licensee MDPI, Basel, Switzerland. This article is an open access article distributed under the terms and conditions of the Creative Commons Attribution (CC BY) license (https:// creativecommons.org/licenses/by/ $4.0 /)$.

\begin{abstract}
The authors have examined municipal waste, its components and their integration with reverse logistics processes. Background: The theoretical part begins with a definition of municipal waste. Later, the integration between municipal waste and reverse logistics is provided, including presentation of the hierarchy of qualitative methods and models. Methods: The authors constructed a correlation matrix and applied a dynamic regression model to identify that the level of municipal waste impacts recycling of biowaste which demands reverse logistics. Results: The authors provided a dynamic regression model which could be applied for forecasting the size of recycled municipal waste into biowaste indicated in European Union countries. Conclusions: The variety of components in municipal waste prevents the increase of the recycling rates and has to be changed to ones that have higher recycling rates.
\end{abstract}

Keywords: municipal waste; packaging; recycling; logistics processes; reverse logistics

\section{Introduction}

Package design is paramount to grabbing buyers' attention. In direct relation to the creation of the packaging, the demand for the product grows [1]. Product packaging design, like branding, is critical to product positioning in the industry and can either drive sales or block sales entirely [2].

The globalisation of modern goods and transactions has presented a new perspective in the return management process [3]. Unfortunately, most companies emphasise getting the product out the door and overlook the need for returns and business management acts as if not expecting the potential return of the shipped product. This gap is often attributed to a deficiency of system automation required to manage the returned product. Indeed, they focus more on immediate reverse logistics customer issues but concentrate less on returns [4].

According to Gartner, Inc., the net profit loss due to improper handling of returns results in loss of control and loss of income and inventory can be estimated to be $35 \%$. Therefore, it is economically prudent and makes good business sense to create an efficient and reliable reverse logistics process [5].

The reverse logistics activities occur during recycling, where packing material is used as a component of municipal waste [6]. The report "The Future of World Packaging to 2022" indicates that the need and demand for packaging will gradually grow by $2.9 \%$ to reach $\$ 980$ billion in 2022. Global packaging sales will increase by 3\% at an annual rate of $4 \%$ from 2018. In Western Europe, packaging sales accounted for 22\%, in North America 23\%, and in Asia even 36\% of total sales [1,2].

The management of municipal waste demands reverse logistics. The physical return triggers reverse logistics processes. The authors investigate the connection points between reverse logistics and municipal waste management.

An analysis of literature (i.e., review of books published by Oxford University Press, Cambridge University Press, Harvard University Press, Springer, M.E. Sharpe, Routledge, 
other publishers was performed and identified that the theme of municipal waste is rarely discussed in the literature on reverse logistics. The analysis presented in Table 1 shows that only 0.49 per cent of the above publications describe investigations in that research area.

Table 1. Review of literature.

\begin{tabular}{cccc}
\hline & & & Thematic of Municipal Waste \\
\hline Year & Literature of Reverse Logistics & Literature of Municipal Waste & Under the Literature of Reverse Logistics \\
\hline $1994-1998$ & 813 & 45,600 & 1 \\
$1999-2003$ & 3460 & 46,300 & 5 \\
$2004-2008$ & 8130 & 44,100 & 10 \\
$2009-2013$ & 11800 & 46,600 & 117 \\
$2014-2018$ & 36600 & 58,200 & 137 \\
$2019-2021$ & 30200 & 61,700 & 473 \\
Total & 91003 & 302,500 & $0.49 \%$ \\
$\%$ & $100 \%$ & & \\
\hline
\end{tabular}

Source: Constructed by authors, according to publications published by Oxford University Press, Cambridge University Press, Harvard University Press, Springer, M.E. Sharpe, Routledge, and other publishers.

Reverse logistics differs from waste management in that it focuses on the addition of value to a product to be recovered and then the outcomes will be used by forward logistics while waste management involves mainly the collection and treatment of the waste products that have got no new use.

That is why the article aims to identify the trends towards recycling and the size of the flows of municipal waste that are recycled. The recycling of municipal waste without the proper organization of waste flows, which are handled by reverse logistics and proper infrastructure, which is a necessity for reverse logistics, is hardly possible.

The article investigates the links between reverse logistics and municipal solid waste management. The article consists of seven main sections. The study starts with the introduction and the summary of the literature. In the second section, the authors discuss the research of various authors to reveal the essential elements of reverse logistics and municipal solid waste management processes. The third section presents the hierarchy of qualitative methods and models for researching reverse logistics and waste collection aspects. The fourth section analysis the role of reverse logistics; and the fifth part-packing and recycling aspects. The sixth section highlights the relationship between a three-level methodology between reverse logistics and municipal waste and describes a dynamic regression model. The seventh section presents results of the dynamic regression model, i.e., helping to forecast the recycled biowaste amounts.

\section{Literature Review}

Reverse logistics is the activity that includes the reverse distribution of materials, as well as reducing the number of new materials in the forward system [7-9]. According to De Brito et al., reverse logistics focuses on the recovery of products when they are no longer desired (end-of-life products such as computers or mobile phones) or can no longer be used (end-of-life products, i.e., tires and packaging) to obtain economic returns through reuse, recycling or recycling in new production [10-12].

Other authors note the importance of environmental requirements and the increasing role of the reverse supply chain in the extraction of materials [13-16]. Valenzuela et al. examined recycling models for plastics based on a reverse logistics model and a waste recycling model and also pointed out that the reverse logistics process is a process from consumption to point of origin that includes the planning, execution and effective control of the costs of raw materials, work in progress, finished goods and related information, to recover the primary value of materials or dispose of them properly [17]. Table 2 presents the main elements of reverse logistics described by different authors. 
Table 2. Essential elements of reverse logistics.

\begin{tabular}{|c|c|c|}
\hline & Elements & References \\
\hline \multirow{17}{*}{$\begin{array}{l}\text { Essential elements of } \\
\text { reverse logistics }\end{array}$} & Operation cost & [18-42] \\
\hline & Recapture value & {$[18,21,24,26,28,30,35,41]$} \\
\hline & Technical feasibility & {$[24,28,29,35,40,42-44]$} \\
\hline & Recycling network & {$[18,19,22,25,26,28-30,33,36,40-48]$} \\
\hline & Return cost & {$[25,30,32,35,42,43,49]$} \\
\hline & Remanufacturing network & {$[18,21,26,30,36,42,44,48-50]$} \\
\hline & Recovery value & {$[18,25,36,44,49,50]$} \\
\hline & Reuse network & {$[18,20,21,27,28,31,33,41-43,45-47,50]$} \\
\hline & Product recovery & {$[18,19,21,23-26,28,30-34,39,42,49,51,52]$} \\
\hline & Environmental impacts & {$[18,20,21,23,24,27-31,33,35,36,38,40-43,45-47,49-53]$} \\
\hline & Service management & {$[18,20,34,37,40,44,49-51,53]$} \\
\hline & Market demand & {$[18,19,30,32,34,37,44,50,53]$} \\
\hline & Sustainable development & {$[22,23,27-31,35-37,40,44-46,51,53,54]$} \\
\hline & Green effect & {$[20,22-27,34-37,39,40,44-46,49,51,52,54]$} \\
\hline & Product return & {$[18,21,23-25,30-32,34-36,39,41,42,45,48,49,54,55]$} \\
\hline & Closed loop supply chain & {$[24-26,29,30,32,35,40,42,50-52,55]$} \\
\hline & End-of-life product & {$[18,19,21-26,35,39,42,43,50,55]$} \\
\hline
\end{tabular}

Table 2 shows that in recent years the publications describing the processes of reverse logistics, necessarily emphasize the impact of such processes on the environment and sustainable development, green effect and others, which are disclosed in more detail in the table.

Municipal solid waste (MSW, as specified in Appendix B) includes refuse from households, non-hazardous solid waste from agriculture areas, commercial and institutional establishments (including hospitals), market waste, yard waste, and street sweepings [56]. MSW, which is defined as waste that is collected and treated by the municipality. MSW is the term applied to domestic waste and domestic-type industrial waste (paper, plastic, electronic appliance waste).

MSW includes everyday items used and then thrown away, called rubbish or trash in everyday life. According to Vergara et al. MSW is all solid or semi-solid materials disposed of by residents and businesses, excluding hazardous wastes and wastewater [57]. MSW includes food packaging, bottles, clothing, furniture, lawn clippings, scraps of foods, newspapers, household appliances, paints, and batteries [14,47]. The primary producers of solid waste are in residential areas such as apartments, houses, companies, schools, hospitals and others.

According to Ogwueleka, MSW management is the management of waste in urban areas in terms of its collection, transfer, treatment, recycling, reuse and disposal [56]. The main goals of MSW management are related to the promotion of the quality of the urban environment, the creation of jobs and income, the protection of environmental health and the maintenance of economic efficiency and productivity $[56,58]$. The definition of MSW does not include building rubble, waste from the demolition of buildings and structures, and wastewater from municipal sewage treatment plants and sewer networks.

Table 3 shows the trends that many authors in their scientific papers emphasize waste management, waste minimization and reduction, green images in the above-mentioned processes. 
Table 3. Essential elements of MSW.

\begin{tabular}{|c|c|c|}
\hline & Elements & References \\
\hline \multirow{14}{*}{$\begin{array}{c}\text { Essential elements } \\
\text { of MSW }\end{array}$} & Waste reusing & {$[18,26,31]$} \\
\hline & Waste incineration & {$[21,23,28,32,42,47]$} \\
\hline & Air emission & {$[22,31,40,47]$} \\
\hline & Carbon footprint & {$[18,20,21,26,30,36,39,46,47,49]$} \\
\hline & Waste recycling & {$[19,21,32,35,37,39,51]$} \\
\hline & Waste disposal & {$[20-26,31,39,41,43,47,51]$} \\
\hline & Zero Waste & {$[21,32,47,51]$} \\
\hline & Responsible use & {$[24,26,31,35,40,41,45,46,51]$} \\
\hline & Waste treatment & {$[22,26,28,29,39,46,52]$} \\
\hline & Waste use for energy & {$[21,26,45,51,53]$} \\
\hline & Green image & {$[18-20,22,24-26,30,34,35,40,42,43,45,46,50,52,54]$} \\
\hline & Waste generation & {$[18-20,22,28,29,31,40,42,43,47,50,55]$} \\
\hline & Waste minimization (reduction) \& recovery & {$[20-22,25-27,29,32,35,40,43,45,47,50-52,55]$} \\
\hline & Waste landfilling & {$[21,23,24,28,30,32,35,42,47,55]$} \\
\hline
\end{tabular}

The similarity of household waste shows how household waste can be classified according to the European classification. It is the European classification possibility proposed by Eurostat for the scope of municipal waste. Waste organisation is based on the principle that municipal waste includes household waste and waste from non-household sources, regardless of the division of responsibility for municipal waste collection that rests with the municipality or individuals [59]. Typical household and commercial solid waste include clothing, disposable utensils, garden waste, cans, disposable office tables, paper and boxes. In contrast, institutional and industrial solid waste includes restaurant waste, paper, school waste, wooden pallets, plastics, corrugated boxes, etc. and office documents $[60,61]$.

\section{Municipal Waste Recovery and Disposal Categories vs. Reverse Logistics}

The authors identify the interface between reverse logistics and MSW. Some directions are identified in previous studies. The authors focus on such directions: (1) the comparison of urban solid waste and municipal governance practices in several European countries to identify the characteristics and main aspects of waste management and physical reverse logistics by modelling logistics for urban solid waste; (2) the improvement of decisions at the operational reverse logistics level for electronic equipment waste; (3) the design of reverse logistics network for electrical and electronic waste in Turkey; (4) the construction of routes used for the management for urban solid waste in Brazil; (5) creation of optimal reverse logistics network for determining the carbon footprint; (6) the production planning for products repair and recycling based on reverse logistics network management and other studies cited in Table 4.

Table 4. Hierarchy of qualitative methods and models for researching reverse logistics and waste collection aspects.

\begin{tabular}{cccc}
\hline Model Type & Model Technique & Solution Method & $\begin{array}{c}\text { References Discussing Reverse } \\
\text { Logistics and Waste Collection }\end{array}$ \\
\hline \multirow{3}{*}{$\begin{array}{c}\text { Mathematical } \\
\text { programming method }\end{array}$} & Single objective & Linear programming & {$[62-66]$} \\
\cline { 2 - 4 } & Multiple objectives & $\begin{array}{c}\text { Mixed-integer linear } \\
\text { programming }\end{array}$ & {$[67-72]$} \\
\cline { 2 - 4 } & & Mixed-integer programming & {$[73,74]$} \\
\hline
\end{tabular}


Table 4. Cont.

\begin{tabular}{|c|c|c|c|}
\hline Model Type & Model Technique & Solution Method & $\begin{array}{l}\text { References Discussing Reverse } \\
\text { Logistics and Waste Collection }\end{array}$ \\
\hline & & Multiple regression & {$[75,76]$} \\
\hline & & Analysis of hierarchical regression & [77] \\
\hline & & Fuzzy-goal programming & [78] \\
\hline & & Stochastic dynamic programming & [79] \\
\hline & & Non-linear programming & {$[80,81]$} \\
\hline & Time series & Dynamic regression analysis & this study \\
\hline \multirow{2}{*}{ Causal models } & \multirow{2}{*}{ Causality identification methods } & Causal effect modelling & [82] \\
\hline & & Diagram of causal systems & [83] \\
\hline \multirow{8}{*}{ Heuristic methods } & Simple heuristic & Simulated annealing heuristics & [84] \\
\hline & \multirow{6}{*}{ Artificial intelligence techniques } & Markov chain & [85] \\
\hline & & Object-oriented Petri nets & [86] \\
\hline & & Bayesian network modelling & [87] \\
\hline & & Fuzzy logic & [88] \\
\hline & & Rough sets & [89] \\
\hline & & Neighbourhood rough sets & [90] \\
\hline & Metaheuristic & $\begin{array}{c}\text { Genetic Algorithm } \\
\text { Multi-objective evolutionary } \\
\text { Algorithm } \\
\text { Multi-objective differential } \\
\text { evolution algorithm } \\
\text { Particle swarm optimisation } \\
\text { Ant Colony Optimization }\end{array}$ & [91-96] \\
\hline \multirow{2}{*}{ Analytical models } & \multirow{2}{*}{ Multi-criteria decision making } & Analytical hierarchy process & [97] \\
\hline & & DEMATEL & [98] \\
\hline \multirow{2}{*}{ Analytical models } & \multirow{2}{*}{ Systematic models } & Delphi method & {$[55,99]$} \\
\hline & & Network model & [100] \\
\hline
\end{tabular}

\section{References Discussng Reverse Logistics and Waste Collection}

[66]

[70]

[71]

[72]

[73]

\section{Description of Study}

Linear model is constructed for co-collecting separated waste streams and for integrating reverse logistics delivery and collection activities.

Linear model is presented production-recycling-reuse of plastic beverage bottles in the context of reverse logistics and waste management.

A manufacturing/remanufacturing inventory model is formed with waste disposal and developed reverse logistics process for energy used.

Linear programming model presents the impact of waste pickers activities logistics network.

Model is suggested for integrated forward-reverse logistics with carbon footprint considerations. MILP model includes reverse logistics networks for returned medical waste seeking to improve medical waste management.

Reverse logistics network is constructed that sources end-of-life products.

Model is developed for the planning and management of the electronic waste collection system in the city of Genoa.

MILP model is formed for determining the best WEEE recycling offer price by determining reverse logistics operation planning strategies.

Optimization reverse logistics activities are described with MILP model of end-of-life vehicle recycling.

Model is developed to determine which recycling strategy is should be selected for commercial waste.

Heuristics is suggested for the configuration of reverse logisticsnetworks serving the recycling of electronic appliances and computers.

Regression method is used to investigate the relationship between food firm competitiveness and reverse logistics attributes important for waste management. 
Table 4. Cont.

\begin{tabular}{|c|c|}
\hline Model Type & $\begin{array}{l}\text { References Discussing Reverse } \\
\text { Logistics and Waste Collection }\end{array}$ \\
\hline [75] & $\begin{array}{l}\text { Major factors are examined that may influence industries toimplement reverse logistics, among which is the } \\
\text { regulation of the waste amount. }\end{array}$ \\
\hline [76] & $\begin{array}{l}\text { Four-step hierarchical regression analysis is used seeking to motivate firms to implement reverse logistics to } \\
\text { handle e-waste. }\end{array}$ \\
\hline [77] & Fuzzy goal programming is presented for a lead/acid battery reverse logistics network design. \\
\hline [78] & $\begin{array}{l}\text { Model of stochastic dynamic programming is presented for reverse logistics interaction with production } \\
\text { planning of the re-manufacturing system, determining the amount of recycled waste. }\end{array}$ \\
\hline [79] & $\begin{array}{l}\text { Non-linear model of multifunctional reverse logistics is constructed for planning and design of an optimal } \\
\text { computer waste management system. }\end{array}$ \\
\hline [81] & $\begin{array}{c}\text { Causal effect model is proposed to describe the need for the collection of agricultural waste (i.e., } \\
\text { pesticide packaging). }\end{array}$ \\
\hline [82] & $\begin{array}{c}\text { Diagram of the causal system is used to create a new WEEE handling system based on two flows a forward } \\
\text { and reverse logistics flows. }\end{array}$ \\
\hline [83] & $\begin{array}{l}\text { Simulated annealing algorithm is tailored to generate a solution using the output of an e-recycling reverse } \\
\text { logistics network. }\end{array}$ \\
\hline [84] & Markov chain approach is used for presenting retailer reverse logistics which deals with waste handling. \\
\hline [85] & Petri net forecasting model is suggested for household waste and model reverse logistics network. \\
\hline [86] & $\begin{array}{c}\text { Bayesian network is constructed for the reverse logistics that are used for product recovery and } \\
\text { waste reduction. }\end{array}$ \\
\hline [87] & Simulation model is presented for reverse logistics network collecting end-of-life appliances. \\
\hline [88] & $\begin{array}{l}\text { Rough set theory is applied to reduce the complexity of the RL for the company involved in } \\
\text { waste management. }\end{array}$ \\
\hline [89] & $\begin{array}{c}\text { Neighborhood rough set conceptual application is developed for management decisions within the context of } \\
\text { reverse logistics and defective products. }\end{array}$ \\
\hline [90] & Genetic algorithm is presented to model the reverse logistics network for medical waste management. \\
\hline [91] & Model is constructed for the selection of solid waste transfer stations under a reverse logistics network. \\
\hline [92] & $\begin{array}{l}\text { Optimization of the flow distribution of e-waste reverse logistics network is researched to obtain Pareto } \\
\text { optimum solution with an evolutionary algorithm. }\end{array}$ \\
\hline [93] & Differential evolution algorithm is used to design product return network to balance costs and loads. \\
\hline [94] & $\begin{array}{c}\text { Reverse logistics network optimization model is proposed which fully considered environment effect and the } \\
\text { waste recycling factors. }\end{array}$ \\
\hline [95] & $\begin{array}{l}\text { Model of multi-objective ant colony optimization (MACO) algorithm is suggested for reducing reverse } \\
\text { logistics cost considering environmental factors was verified through a simulation on waste textile product } \\
\text { reverse logistics. }\end{array}$ \\
\hline [96] & $\begin{array}{l}\text { AHP technique is proposed for the decision-making process to evaluate strategies for obtaining optimal } \\
\text { strategies in reverse logistics that collects used products as a waste. }\end{array}$ \\
\hline [97] & $\begin{array}{l}\text { DEMATEL technique is suggested as a decision-making tool used to design reverse logistics for collecting } \\
\text { textile waste. }\end{array}$ \\
\hline [55] & $\begin{array}{l}\text { Delphi method is used to develop a model to select the most appropriate firms for the treatment of infectious } \\
\text { waste objectively and efficiently. }\end{array}$ \\
\hline [98] & Solution is proposed for assessing the green practices including reverse logistics and use of waste. \\
\hline [99] & $\begin{array}{l}\text { Network model is presented to rank the alternatives for implementing the process of reverse logistics, which } \\
\text { include three major stages: waste collecting, sorting and reprocessing. }\end{array}$ \\
\hline
\end{tabular}

In Table 4, the authors examined the type of qualitative methods and models dedicated to reverse logistics and waste collection are used by other authors for their research. Among the methods, the most popular is the mixed-integer linear programming method in studies dedicated to the above-mentioned topic [100]. The authors identified that the dynamic regression model is not mentioned among above listed quantitative methods. Time series analysis could help to identify the capacity that is required to handle reverse logistics at different periods to perform waste collection and recycling. 
Reverse logistics principle, evaluation and recycling of organic waste is relevant for both developing and economically developed countries from the point of view of solving current problems in waste management. Reverse logistics focuses on adding value to the product to be disposed of.

The implementation of life cycle processes (LCA) is an essential tool in reverse logistics. The life cycle assessment includes alternative material concepts and various components from the extraction of raw materials through the use phase to recycling; alternative ideas are implemented over the entire product life cycle, starting with the development process [101,102].

In Table 5, the authors briefly summarize the main sources and types of waste, with a description next to each.

Table 5. Municipal waste by source and types, modified by authors following [103].

\begin{tabular}{|c|c|c|}
\hline MSW Source & Types of Solid Waste & Description \\
\hline Agriculture & $\begin{array}{l}\text { Solid waste, which includes waste from the food and } \\
\text { meat processing industries, industrial, agricultural, } \\
\text { yard, garden and plant debris, and medical solid } \\
\text { waste, as well as hazardous solid and chemical waste }\end{array}$ & $\begin{array}{l}\text { Agricultural activities associated with the } \\
\text { preparation, production, storage, processing, and } \\
\text { consumption of agricultural products, livestock, } \\
\text { and processed products generally generate solid } \\
\text { agrarian waste. }\end{array}$ \\
\hline Commercial & $\begin{array}{l}\text { Food wastes, metals, glass, special wastes, plastics, } \\
\text { paper, cardboard, wood, hazardous wastes }\end{array}$ & $\begin{array}{l}\text { Commercial Waste or MSW is produced in } \\
\text { businesses and includes general waste, mixed } \\
\text { dry recyclables and organic waste. }\end{array}$ \\
\hline Household & $\begin{array}{l}\text { Textiles, food wastes, metals, glass, special wastes } \\
\text { (batteries, consumer electronics, oil, tires, bulky } \\
\text { items), plastics, paper, cardboard, wood, ashes, } \\
\text { household hazardous wastes }\end{array}$ & $\begin{array}{l}\text { Household Waste or MSW is produced in our } \\
\text { homes and includes general waste, mixed dry } \\
\text { recyclables and organic waste. }\end{array}$ \\
\hline Institutional & $\begin{array}{l}\text { Food wastes, metals, glass, special wastes, plastics, } \\
\text { paper, cardboard, wood, hazardous wastes }\end{array}$ & $\begin{array}{l}\text { Actions address waste materials originating in } \\
\text { institutional facilities, such as government } \\
\text { offices, schools, hospitals, nursing homes, } \\
\text { correctional facilities, research institutions and } \\
\text { public buildings. }\end{array}$ \\
\hline Municipal service & $\begin{array}{l}\text { Street-cleaning residues, trimmings landscape and } \\
\text { trees, collecting general wastes from recreational } \\
\text { areas (such as parks, beaches, etc.) }\end{array}$ & $\begin{array}{l}\text { Household waste and waste of a similar type } \\
\text { and composition are taken into account by } \\
\text { municipal waste. }\end{array}$ \\
\hline
\end{tabular}

Commercial household waste has similar properties and composition to household waste. Such waste can be collected separately from household waste in removable containers [104-106]. The waste management pyramid defines levels of waste prevention and management. Under the waste management pyramid there are stated waste management steps, which should be named [107-109]:

1. reduced,

2. reused,

3. repaired,

4. recycled,

5. recovered,

6. composted,

7. incinerated,

8. landfilled.

Reverse logistics are the processes of planning, implementation and control of the return flow of raw materials, production stocks, packaging and finished goods from the original production, distribution or use location to the final disposal. The flow goes from the customer, more precisely from the point of consumption to the manufacturer, more precisely to the place of origin, to dispose of them properly or to return the value. 
This activity is due to some aspects of environmental protection. However, most of them relate to issues respecting the correct distribution of waste. From this, we can conclude that reverse logistics is associated with garbage, especially those that are suitable for processes that restore their useful functions and for processes that are safe distance $[17,110]$.

Based on reverse logistics, the ultimate goal of a company must be resources reduction, that is, waste and energy savings producing greener products reduction $[20,21,26]$. In such cases, the company should reuse the materials and make an effort to maximise waste recycling. In this case, reverse logistics at the end of the chain would focus on waste disposal [52,86]. Any predictable returns or pattern that recurs or repeats over one year is said to be a seasonal return.

Reusing waste management, proper handling and recycling, that is, activities in the return channel indicates the connection between waste management and take-back logistics $[14,15,17,110]$. Remove items-any waste management element that needs to be removed.

When it comes to waste management, reverse logistics plays a vital role [6,7]. As we can see in Figure in Appendix A, reverse logistics is a process that allows organisations to reuse, reduce, use energy, landfill and recycle waste generated at various points in their value chain $[18,34]$.

The links between the supply chain, return logistics and waste management processes are also evident in the diagram [16,35]. Returning goods will always be part of the business, but it is not worth considering only an operating expense. Properly implemented reverse logistics processes can improve a company's performance [3,15]. In addition, better management of returned goods will help reduce waste and generate higher profits, as the same goods can be reused [103,104].

Reverse logistics differs from traditional waste management in that it adds value back into the chain by recovering and repurposing products, while waste management mainly focuses on disposal [109]. Fundamental to reverse logistics is offering efficient, potentially profit-generating methods of disposing of end-of-life products and waste [17,110]. A well-integrated waste management system encompasses government, business and society [10,61,107].

What is considered a waste to someone today may be a resource in the future, asserted by the authors $[111,112]$. They further point out that waste in one industry may be a raw material in another industry in recent industrial development.

Municipal waste and waste, in general, can be treated as redundant objects, which have lost their initial functionality, but that present value in terms of their secondary function [113,114].

Table 6 shows that the municipal waste is distributed according to recycling, landfill, incineration, composting by million tones and by kilograms per capita in the years from 2010 to 2019, when the numbers are presented as the European Union average [115]. The numbers of recycling and composting are growing. However, the volume of landfills is decreasing, and waste incineration is increasing. The environmental impact of incinerated waste is highly dependent on the nature of the trash that is disposed of.

Table 6. Municipal waste by waste management operations, EU-27, 2010-2019 [116].

\begin{tabular}{lcccccccccccc}
\hline & $\mathbf{2 0 1 0}$ & $\mathbf{2 0 1 1}$ & $\mathbf{2 0 1 2}$ & $\mathbf{2 0 1 3}$ & $\mathbf{2 0 1 4}$ & $\mathbf{2 0 1 5}$ & $\mathbf{2 0 1 6}$ & $\mathbf{2 0 1 7}$ & $\mathbf{2 0 1 8}$ & $\mathbf{2 0 1 9}$ \\
\hline Recycling & 55 & 56 & 58 & 56 & 59 & 63 & 65 & 66 & 67 & 68 \\
\hline Composting & 29 & 29 & 30 & 31 & 33 & 33 & 36 & 38 & 38 & 39 \\
\hline Incineration & 53 & 55 & 54 & 56 & 57 & 57 & 58 & 59 & 59 & 60 \\
\hline Landfill & 79 & 74 & 67 & 63 & 59 & 57 & 54 & 53 & 52 & 53 \\
\hline Other & 6 & 6 & 6 & 5 & 4 & 4 & 5 & 6 & 6 & 4 \\
\hline
\end{tabular}


Table 6. Cont.

\begin{tabular}{lcccccccccccc}
\hline & $\mathbf{2 0 1 0}$ & $\mathbf{2 0 1 1}$ & $\mathbf{2 0 1 2}$ & $\mathbf{2 0 1 3}$ & $\mathbf{2 0 1 4}$ & $\mathbf{2 0 1 5}$ & $\mathbf{2 0 1 6}$ & $\mathbf{2 0 1 7}$ & $\mathbf{2 0 1 8}$ & $\mathbf{2 0 1 9}$ \\
\hline Recycling & 125 & 128 & 130 & 128 & 134 & 141 & 146 & 148 & 149 & 152 \\
\hline Composting & 66 & 66 & 69 & 71 & 73 & 75 & 82 & 85 & 84 & 87 \\
\hline Incineration & 121 & 125 & 122 & 127 & 128 & 128 & 131 & 132 & 132 & 134 \\
\hline Landfill & 178 & 167 & 153 & 142 & 134 & 127 & 121 & 118 & 116 & 119 \\
\hline Other & 13 & 13 & 14 & 10 & 9 & 9 & 10 & 13 & 13 & 10 \\
\hline
\end{tabular}

During recycling, waste is recycled into products or materials. Waste is sorted from the general waste stream [117]. In such cases, on-site processing in industrial plants is excluded. Other categories of waste are composition or decomposition. The processing of organic substances by aerobic or anaerobic processes and the processing into substances that can be used as fuels and for energy generation do not belong to the waste treatment category. In the case of household waste, they are recycled directly or after their pre-treatment.

Both composting and decomposition are biological processes in which biodegradable waste is decomposed aerobically or anaerobically. The products of these processes are composted or gestate. After any further processing, agriculture benefits or in the hope of using it wisely, the ecology is used as a recycled product or as a material for tillage [118]. Municipal waste can be composted directly or after pre-treatment [119]. If the product after treatment is subsequently disposed of in a landfill, incinerated or otherwise not used for the above purpose, in which case the biological treatment of the waste MBT (mechanical-biological treatment) cannot be considered as composting [118]. Wastes from composting/fermentation and incineration of debris from another recovery/disposal operation to be recycled materials as metals [115,120].

Incineration is the thermal treatment of waste in an incineration plant. Incinerate immediately or after pre-treatment, possibly municipal waste. Incineration of municipal waste makes it possible to obtain as secondary fuel [107,121,122].

The landfill is defined as waste discharge into the ground and temporary storage in permanent places for more than one year [120]. Landfills with internal (waste generator itself eliminates waste generation) and external sites are defined. Municipal waste is disposed of in landfills either directly or after pre-treatment. If a sorting step is performed in the landfill area, the sorting results are assigned to the proper recovery/disposal operations $[103,110]$.

\section{The Role of Reverse Logistics}

Reverse logistics processes offer companies the opportunity to become more environmentally friendly through reuse, recycling and recovery [5,15]. A material reduction in a direct system based on minimum return quantities, possible material reuse, and simplified recycling create a more comprehensive picture of reverse logistics [109].

The traditional supply chain uses resources from the environment. Such resources are converted into valuable products, and the cycle is considered complete when the product arrives and is distributed among consumers [121-124]. It is noteworthy that secondary raw materials follow "reverse sales channels", which are more associated with a reverse logistics strategy than with a method of using traditional sales and logistics channels [125]. Reverse logistics is defined as "... the role of logistics in product returns, serving activities such as reduction, recycling, material replacement, material reuse, waste disposal and recycling, repair and recovery ... " [126]. In reverse logistics, an integrated approach is used to be successful. By definition, reverse logistic activities take many forms. Rogers and Tib-ben-Lembke [124] classify the list of possible reverse logistics actions. The activities are classified according to the materials used in products and packages in which products are delivered (see Table 7). 
Table 7. Reverse Logistics serving Activities, constructed by the authors following [123].

\begin{tabular}{cc}
\hline Materials in & Reverse Logistics Serves such Activities \\
\hline & Reduce \\
& Reuse \\
Package \& Products & Repair \\
& Recycle \\
& Recover \\
& Compost \\
Incinerate \\
Landfill
\end{tabular}

In Table 7, the authors highlight the main activities served by reverse logistics.

Reduce is an activity that minimises the quantity and use of materials that cannot be recycled.

Reuse-an activity to clean, repair products and materials in products for reuse without any pre-processing steps.

Repair-the fixing of broken items in products and materials.

Recycling is the removal of material from a recycled product or package. These are carried out to recycle a product or packaging as raw material for a new product or packaging $[127,128]$. During waste collection, the driver should know that will be the further step. If the waste will be recycled the driver should not mix different waste streams by putting them into the truck.

Recover activity uses technologies and methods allowing to recover materials from mixed wastes.

Composting-activity, which separately collected waste converts into biowaste.

Incineration is an activity, which helps to transform waste into energy, plastics to fuels, and other resources.

The landfill is a site for the disposal of waste materials, also known as a tip, dump, rubbish dump, garbage dump, or dumping ground.

The main problem is that all products and/or packaging are sent to landfill when recycling is not involved [129].

When forward logistics end, reverse logistics begins. In the beginning, consumers buy the product they need, such as a newspaper or a soft drink. After reading a newspaper or drinking a soft drink, the product usually runs out, or the newspaper read becomes irrelevant, the product's useful life ends [130]. And then, consumers have to decide how to dispose of waste properly. It depends on consumers decision to dispose of leftover packaging or unwanted newspapers. Their choices are potentially substantial long-term effects on the environment [131]. Several factors must be considered, such as the activities that encourage a particular disposal method or financial incentives.

The reason for this is that in many cases, the price of the container, such as an empty soda bottle or a used newspaper, is not apparent to consumers or manufacturers, so there may be an incentive to recycle used raw materials be pretty low. The value of such a secondary or residual product will only increase as a potential raw material for a new product [129]. Therefore, the supply and demand for secondary raw materials must be developed to have value from new raw materials. The focus here is on reverse logistics.

\section{Packing and Recycling}

The packaging protects products that are placed on the market for sale, storage, use, etc. The packing generally relates to the design, evaluation and manufacture of packaging. Packing is critical for the movement of products that are distributed in large quantities. Improper packing could cause handling problems during reverse logistics activities. Common packaging materials are boxes, cardboard boxes, cans, bottles, pouches, envelopes, packages, and containers [132]. 
The increased demand for packaging has led many companies to look for methods and ways to improve packaging design to increase sales of their products [133]. Attractive, durable packaging design not only protects goods from damage and/or breakage but also helps to attract the end user's attention.

Packaging types and methods are presented in Table 8.

In Table 8 the authors briefly summarize the main packaging types and methods, with a description next to each.

Decisions about the choice of primary, secondary and tertiary packaging are of great strategic importance. In this article, we describe the key concepts for choosing product packaging from a logistics perspective and the difference between primary, secondary, and tertiary packaging [134-137].

Primary packaging is designed to contain, store and protect products. It is in direct contact with the product and is designed to keep it in optimal conditions. This packaging is the least used, so it does not complicate a single sale of goods. Primary packaging forms are jars, cans, bags, bottles, sacks, etc., [138].

Secondary packaging consists of an aggregate of primary packaging. This type of packing further protects the product and makes it easier to market on a larger scale. These are mainly cardboard boxes, although they can also be plastic. For example, in the case of milk, a single carton would be the primary packaging, and the carton containing the carton would account for the secondary packaging [138,139].

We need tertiary packaging to create larger units of loads, which includes primary and secondary. The most common forms of tertiary packaging are pallets, containers, and the modular cartons they contain. A distinction is made between three packaging types, which depend on the function and purpose: individual packaging, inner packaging and outer packaging $[138,140]$.

Individual packaging is used for packaging each particular product. The unique packaging aims to protect the product from various climatic influences such as cold, heat, moisture, light, and wind [141].

The inner packaging is a unit that is sold in retail stores. It is used to bundle or group individually packaged products into a unit, such as lollipops in pouches. Each individually packaged candy is additionally grouped by weight in a single pack. Attractive packaging design is essential to arouse the consumer's desire to buy and thus to stimulate sales. It is, therefore, necessary to pay attention to the interior design of the packaging [142].

The most extensive packaging in which products are packaged in outer packaging is the outer packaging, such as cardboard boxes or wooden boxes. The primary purpose of the outer packaging is to protect products from breakage, dirt and elements [143].

Following the pyramid of plastic waste management, it is vital to prevent plastic use, reduce unnecessary plastics, and use reusable plastics designed for long life. It is suggested to recycle low-value plastics and produce recyclable high-value materials.

Recycling is understood to mean the flow of valuable materials [7,124]. For example, the bottle-from-bottle recycling method leads the industry and results in $100 \%$ recycled plastic used in bottles for cleaning and handwashing. Thus, recycling achieves a good green triple effect: less waste is sent to landfills, 70\% less energy (as primary energy) is used for resin production and beautiful bottles are made from recycled plastic [144].

- For hand washing detergents, dishwashing detergents and sprays made from $100 \%$ PCR (post-consumer recycled), 100\% recycled plastic is used, i.e., all plastic bottles made from 1-PET. Compared to using pure plastic, PCR has about $70 \%$ less carbon footprint.

- $\quad 50 \%$ recycled plastic is used in 2-HDPE bottles, ranging from $25 \%$ PCR in our toilet cleaners to $50 \%$ PCR in our detergent with $8 \times$ magnification.

Recyclable design is a closed packaging solution. With this in mind, recycling systems have been carefully researched to determine which plastics and packaging materials are suitable for recycling. Bottles are designed to be compatible with this purpose whenever 
possible. With this method, all packaging is developed to maximise recycled content, materials, efficiency and recyclability [145].

Table 8. Packaging types and methods.

\begin{tabular}{|c|c|}
\hline Packaging Types & Packaging Methods \\
\hline Anti-corrosive Packaging & $\begin{array}{l}\text { - } \quad \text { Papers and films with volatile } \\
\text { corrosion protection (VCI) } \\
\text { - } \quad \text { Moisture-absorbing barrier } \\
\text { - } \quad \text { Oluminium foil } \\
\end{array}$ \\
\hline
\end{tabular}

Packaging of Pharma [50]

- Primary Package

- Secondary Package

- Tertiary package

\section{Description}

Corrosion protection packaging should protect products from corrosion and avoid lengthy operations. Various materials are used to protect goods from the effects of different climatic conditions, such as paper, oil, bubble wrap with VCI, chips and bags, which are used as part of the anti-corrosion package.

During packaging of drugs or pharmaceuticals, the package goes through processes from production plants via distributing companies to end consumers.

The package of pharmaceutical products is designed to ensure drug safety, ease of use and product safety upon delivery. The primary purpose of pharma packaging is to equip vital medicines for surgical devices, blood and blood products, liquid and bulk dosage forms, and solid and semi-solid dosage forms while maintaining their original condition and properties. The packaging described is used for delivery, etc.

Plastic packaging is mainly used for packaging various items such as fragile or non-perishable products. In addition, plastic packaging materials are used for coating materials or plastic-related products. For reuse in their factories, most plastic packaging companies recycle waste or plastic waste and offer alternatives.

Flexible packaging can be easily reshaped and defined as any packaging. If you choose flexible packaging, it has some benefits:

- $\quad$ Provides safety for food products and shelf life indications through heat seal tightness, clogging prevention, ease use solutions and high print quality.

- $\quad$ This packaging type generally reduces landfill waste as it creates little waste in printing processes.

- Improvement of the production processes, reducing greenhouse gas emissions and volatile organic compounds, energy consumption, and water.

- By using lighter and more flexible bags, more respect for nature, a lower environmental impact and lower consumption of energy and fossil fuel during transport are achieved.

* PET or PETE-Polyethylene Terephthalate, HDPE—High-Density Polyethylene, LDPE—Low-Density Polyethylene, PV—Polyvinyl, PP-Polypropylene, PS-Polystyrene.

The refuelling method ensures that only the required amount of plastic and other materials are used. Most of the plastic waste consists of containers and packaging. Almost 
$13 \%$ of all solid household waste is made up of various plastics. When looking for ways to make packaging as green as possible, researchers always emphasise the need to find additional ways to reduce environmental impact. For example, easy-to-use bags for replenishing supplies for manual, automatic, and dishwashing detergent save around $80 \%$ of plastic, water, and energy compared to a disposable bottle [146].

Different possibilities of recycling flexible packaging and plastic materials $[136,147]$ :

- Polyethene terephthalate is the easiest to recycle. It is widely used in beverage bottles and food packaging (PET or PETE).

- High-density polyethene usually is used recycled into plastic bottles and bags, also used for thicker bottles for motor oil, bleach, and hair products (HDPE).

- A thinner, low-density polyethene is used to make plastic freezer bags and grocery bags. It can be recycled back into plastic bags (LDPE).

- Polyvinyl chloride is difficult to recycle and is environmentally hazardous, but it is used to manufacture furniture and pipes (PVC).

- Fibre plastic-polypropylene can be recycled into fibre materials for further use in clothing, roper, and other ways (PP).

- Polystyrene is used to make packaging materials, foam cups and other lightweight products. Because of its low density, it is difficult to recycle, but it can be reused (PS).

- Other plastics include polymer fibres, acrylic, polycarbonate, nylon, and fibreglass.

In industry, it's a good idea to assess the optimisation level of the packaging in terms of the material it is made of, transportation, handling and storage, waste management, and cost. Only with the overview of the process will you be able to choose the logistics packaging best suited to the company's application $[148,149]$.

To raise awareness among customers, help them increase sales, and make them aware of the latest trends, many companies use the packaging methods listed in Table 9.

Table 9. Types of plastics and the examples of their applications in packing.

\begin{tabular}{|c|c|}
\hline Plastics Types & Examples of Applications \\
\hline Polyethene terephthalate (PET or PETE) & Fizzy bottles, bleach, cleaners and most shampoo bottles \\
\hline High-density polyethene (HDPE) & Most shampoo and cleaner bottles, bleach, milk bottles \\
\hline Polyvinyl chloride (PVC) & $\begin{array}{c}\text { Thermal insulation (PVC foam) and auto parts, fittings, pipes, door and } \\
\text { window frames (hard PVC) }\end{array}$ \\
\hline A thinner, low-density polyethene (LDPE) & Bin liners, packaging films, carrier bags \\
\hline Fibre plastic-polypropylene (PP) & $\begin{array}{l}\text { Microwave-safe food bowls, margarine barrels, carpet fibres and threads, } \\
\text { wall coverings and upholstery for automobiles }\end{array}$ \\
\hline Polystyrene (PS) & $\begin{array}{l}\text { The insulating material in construction, foam boxes for eggs and } \\
\text { hamburgers, plastic cutlery and plastic cups for yoghurt, protective } \\
\text { packaging for electronic items and toys }\end{array}$ \\
\hline Other plastics & $\begin{array}{l}\text { Plastics that do not fall into any of the categories listed above, such as B. } \\
\text { Polycarbonate, which is widely used in the aerospace industry for glazing }\end{array}$ \\
\hline
\end{tabular}

In Table 9, the authors provide examples of how individual types of plastics can be used in packaging.

By choosing these methods, the packing of products delivers ideal results. Using these packaging methods, the shelf life of the products is extended, and competitive advantage is created. In addition, innovative packaging design maximises product profitability [138-149].

\section{Materials and Methods}

The collection of municipal waste involves operations of reverse logistics, including sorting, storing, and transportation. This study aims to figure out the effective actions important for decision-making helping to achieve sustainable development.

Various stakeholders make decisions: 
- $\quad$ Producers, which decide which materials have to be used in products and in which volume, what should be their packing materials and what should be production methods;

- $\quad$ Retailers, which select and provide packing materials to consumers;

- Consumers, which apply to sort and products reuse practices;

- Logistics service providers implement a reverse logistics service management system.

The authors divided the methodology into three layers which present the connections of municipal waste and reverse logistics (see Table 10).

Table 10. Three-level methodology highlighting the connection between municipal waste and reverse logistics.

\begin{tabular}{|c|c|c|c|c|}
\hline Level & $\begin{array}{l}\text { Relationship to } \\
\text { Reverse Logistics }\end{array}$ & $\begin{array}{l}\text { Description of Municipal } \\
\text { Waste Generation } \\
\text { Minimisation by Stages }\end{array}$ & $\begin{array}{l}\text { The Application } \\
\text { of Methods }\end{array}$ & Links with Sustainability \\
\hline $\begin{array}{l}\text { 1st level } \\
\text { Use of environmentally } \\
\text { friendly materials }\end{array}$ & $\begin{array}{l}\text { The physical system } \\
\text { supports the production } \\
\text { and the reduction of the } \\
\text { use of material. }\end{array}$ & $\begin{array}{l}\text { - Selection of } \\
\text { recycling supporting } \\
\text { products and } \\
\text { packing materials } \\
\text { during production } \\
\text { and selling stage. }\end{array}$ & $\begin{array}{ll}\text { - } & \text { Review of } \\
\text { literature;Statistical } \\
\text { analysis; } \\
\text { - } \quad \text { Statistical analysis. }\end{array}$ & $\begin{array}{l}\text { The decision helps } \\
\text { to minimise the } \\
\text { negative impact on } \\
\text { the environment. }\end{array}$ \\
\hline $\begin{array}{l}\text { 2nd level } \\
\text { Collection of } \\
\text { municipal waste }\end{array}$ & $\begin{array}{l}\text { The physical system is } \\
\text { used for the collection of } \\
\text { municipal waste from } \\
\text { end-users. }\end{array}$ & $\begin{array}{l}\text { Sorting during the } \\
\text { collection of } \\
\text { municipal waste. }\end{array}$ & $\begin{array}{l}\text { - } \quad \text { Panel data analysis; } \\
\text { - } \quad \text { Regression analysis. }\end{array}$ & $\begin{array}{l}\text { Waste reduction and } \\
\text { long-term } \\
\text { sustainability } \\
\text { supporting system. }\end{array}$ \\
\hline $\begin{array}{l}\text { 3rd level } \\
\text { Transformation of } \\
\text { collected municipal waste }\end{array}$ & $\begin{array}{l}\text { The physical system that } \\
\text { supports recycling. }\end{array}$ & $\begin{array}{l}\text { Selection of methods } \\
\text { that allows } \\
\text { prolonging the life } \\
\text { of materials. }\end{array}$ & $\begin{array}{ll}- & \text { Comparison; } \\
- & \text { Investigations. }\end{array}$ & $\begin{array}{l}\text { Decision helping to } \\
\text { save natural } \\
\text { resources. }\end{array}$ \\
\hline
\end{tabular}

Table 10 provides a summary highlighting the link between municipal waste and reverse logistics with the help of a three-level methodology, providing descriptions, relationships and methods specific to each level.

For the research, the authors used such indicators, such as

(1) Recycling of biowaste;

(2) The recycling rate of e-waste;

(3) The recycling rate of municipal waste;

(4) The recycling rate of packaging waste by type of packaging.

The yearly data was retrieved from Eurostat for 30 European countries (27 European Union countries, Island, Norway and United Kingdom) for the period 2000-2019 [120]. In total it was 4359 data sets with the values.

The authors revised the data, constructed a correlation matrix and selected for the regression model only elements that have a probability lower than 0.1 (Table 11). The novelty of the study is that the authors constructed a dynamic regression model, by analysing the impact in year $t$ and year $t-n$. The authors of this work use the dynamic regression model first applied by Petris et al. [150]. The first step in the modelling procedure was the transformation of time series to help identify the dependent variable and its relationships to the regressors. The developed model meets the requirements important for the construction of a simple regression model but provides dynamic interrelationships. 
Table 11. Correlation matrix of variables transformed into dlog.

\begin{tabular}{|c|c|c|c|c|c|}
\hline \multicolumn{6}{|l|}{ Covariance Analysis: Ordinary } \\
\hline \multicolumn{6}{|l|}{ Sample: 56577} \\
\hline \multicolumn{6}{|l|}{ Included observations: 40} \\
\hline & & $\begin{array}{l}\text { Recycling of } \\
\text { biowaste }\end{array}$ & $\begin{array}{l}\text { Recycling rate of } \\
\text { e-waste }\end{array}$ & $\begin{array}{l}\text { Recycling rate of } \\
\text { municipal waste }\end{array}$ & $\begin{array}{l}\text { Recycling rate of } \\
\text { packaging waste by } \\
\text { type of packaging }\end{array}$ \\
\hline Recycling of biowaste & $\begin{array}{l}\text { Correlation coeficient } \\
\text { Probability }\end{array}$ & $\begin{array}{r}1.0 \\
-\end{array}$ & & & \\
\hline Recycling rate of e-waste & $\begin{array}{l}\text { Correlation coeficient } \\
\text { Probability }\end{array}$ & $\begin{array}{r}-0.08 \\
0.59\end{array}$ & $\begin{array}{r}1.0 \\
-\end{array}$ & & \\
\hline Recycling rate of e-waste $(-1)$ & $\begin{array}{l}\text { Correlation coeficient } \\
\text { Probability }\end{array}$ & $\begin{array}{l}0.10 \\
0.52\end{array}$ & $\begin{array}{l}0.10 \\
0.53\end{array}$ & & \\
\hline Recycling rate of municipal waste & $\begin{array}{l}\text { Correlation coeficient } \\
\text { Probability }\end{array}$ & $\begin{array}{r}0.86 \\
0,0\end{array}$ & $\begin{array}{r}-0.17 \\
0.26\end{array}$ & 1.0 & \\
\hline Recycling rate of municipal waste $(-1)$ & $\begin{array}{l}\text { Correlation coeficient } \\
\text { Probability }\end{array}$ & $\begin{array}{l}0.26 \\
0.09\end{array}$ & $\begin{array}{l}0.31 \\
0.04\end{array}$ & $\begin{array}{l}0.38 \\
0.01\end{array}$ & \\
\hline Recycling rate of packaging waste by type of packaging & $\begin{array}{l}\text { Correlation coeficient } \\
\text { Probability }\end{array}$ & $\begin{array}{l}0.36 \\
0.02\end{array}$ & $\begin{array}{r}-0.07 \\
0.65\end{array}$ & $\begin{array}{l}0.54 \\
0.00\end{array}$ & 1.0 \\
\hline Recycling rate of packaging waste by type of packaging $(-1)$ & $\begin{array}{l}\text { Correlation coeficient } \\
\text { Probability }\end{array}$ & $\begin{array}{r}-0.15 \\
0.35\end{array}$ & $\begin{array}{l}0.17 \\
0.29\end{array}$ & $\begin{array}{r}-0.06 \\
0.70\end{array}$ & $\begin{array}{r}-0.24 \\
0.12\end{array}$ \\
\hline
\end{tabular}

Table 11 summarizes the correlation analysis performed for this study, noting the level of correlation between the elements listed in the table. The constructed Table 11 shows the link between the recycled rate of packing waste and the recycled rate of municipal waste, as packing waste is part of municipal waste. Table 11 indicates that for the recycling of biowaste the recycling rate of municipal waste (with probability 0 ) the same year strongly correlates.

The authors constructed a dynamic regression model helping to identify the amount of biowaste that is recycled. The completed equation is presented below (1).

The authors use the regressors in constructing mathematical equation:

$$
\text { rec_biow }{ }_{t}=\beta_{0}+\beta_{1} \text { rec_biow }(t-n)+\beta_{2} \text { rec_mu } u_{(t-n)}+u_{t}
$$

where: rec_biow $t_{t}$-dlog of recycling of biowaste in year $t$, which is expressed in $\mathrm{kg}$ per capita; $\beta_{0}$-intercept in the equation; rec_biow $(t-n)$-dlog of recycling of biowaste, in year $t-n$, which is expressed in $\mathrm{kg}$ per capita; rec_ $m u_{(t-n)}$-dlog of recycling rate of municipal waste, in year $t-n$, which is expressed in $\mathrm{kg}$ per capita; $u_{t}$-random error of regression model and $\beta_{1,2}$ - the influence of regressors on biowaste processing reflected coefficients of elasticity.

\section{Results}

The results show that residuals of the equation spread following normal distribution (Figure 1).

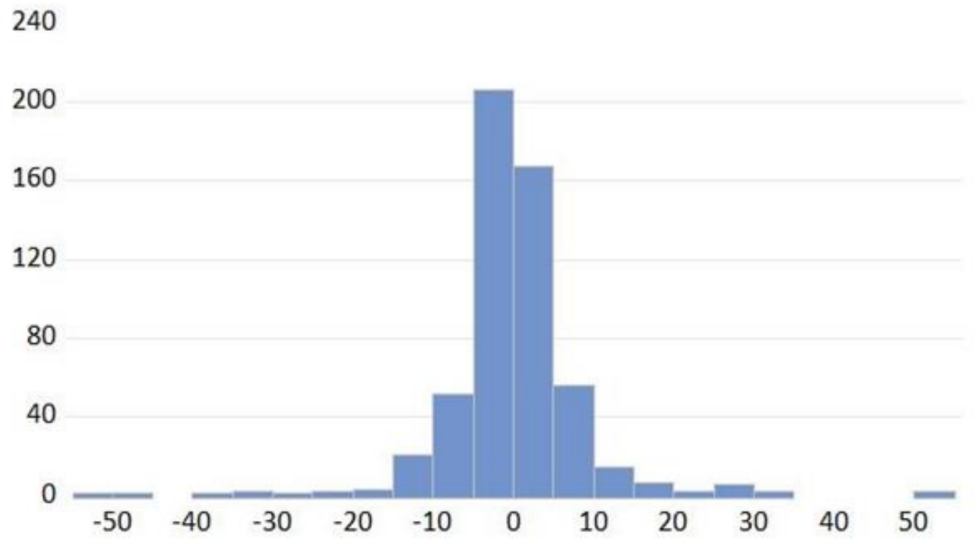

\begin{tabular}{|c|c|}
\hline \multicolumn{2}{|c|}{$\begin{array}{l}\text { Series: Standardized } \\
\text { Sample } 20012019\end{array}$} \\
\hline Observation & 15547 \\
\hline Mean & $-7.72 \mathrm{e}-15$ \\
\hline Median & -0.383281 \\
\hline Maximum & 54.61772 \\
\hline Minimum & -52.50468 \\
\hline Std. Dev. & 8.534398 \\
\hline Skewness & 0.308606 \\
\hline Kurtosis & 14.63431 \\
\hline Jarque-Bera & 3093.696 \\
\hline Probability & 0.000000 \\
\hline
\end{tabular}

Figure 1. Normal distribution formed from equation residuals. 
Figure 1 shows that the average of residuals approximates to zero. The forecasting of volumes of the recycled biowaste are presented in Figure 2.

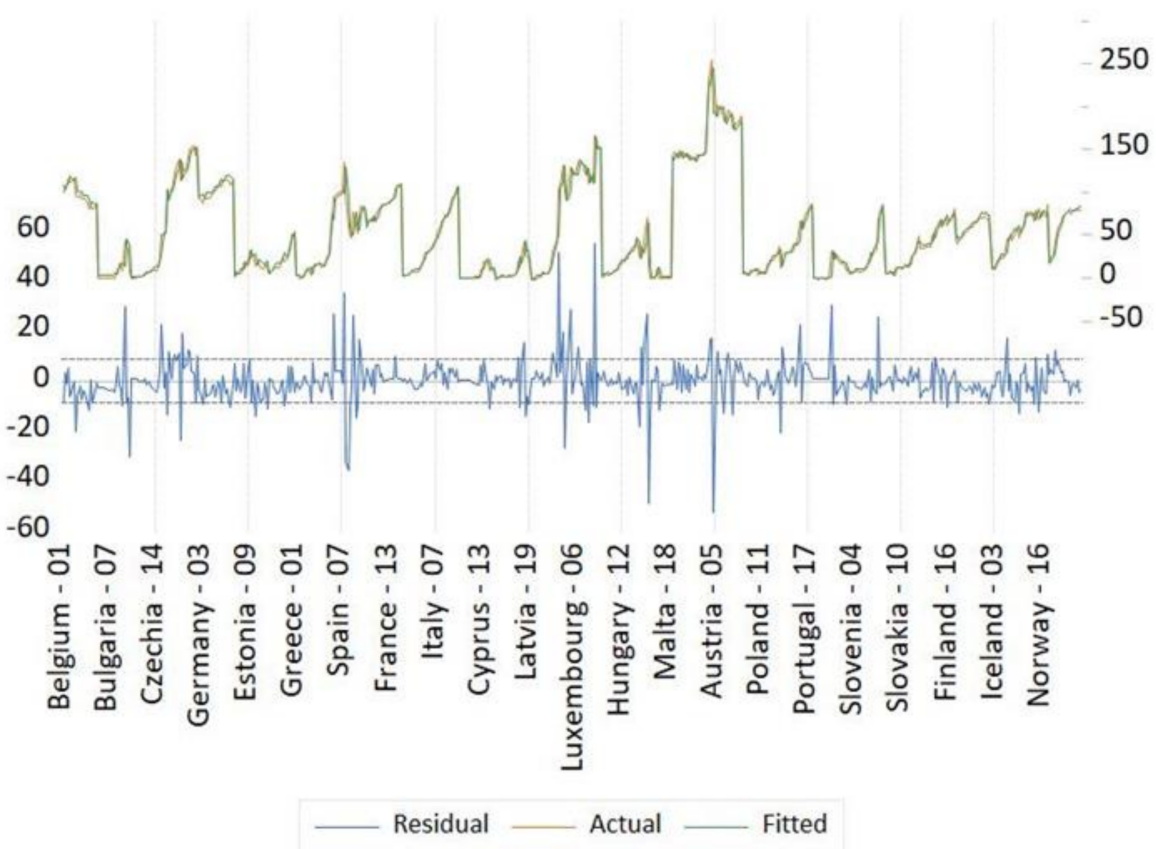

Figure 2. Forecasting the recycled biowaste level by the European Union countries.

The formed equation of the dynamic regression model is specified below (2) by defining coefficients and standard error:

$$
\begin{array}{r}
\text { rec_biow }{ }_{t}=-1.1+0.091 \text { rec_biow } \\
(0.75)(0.012) \rightarrow(0.036)
\end{array}
$$

Seeking to identify concrete values for dynamic regression model (2), the authors used the Panel least squares method and presented the results of method application in Figure 3. Where Durbin-Watson statistics is 2.20.

\begin{tabular}{crlrr}
\hline \multicolumn{1}{c}{ Variable } & Coefficient & Std. Error & t-Statistic & Prob. \\
\hline \hline C & -1.104664 & 0.752624 & -1.467750 & 0.1428 \\
REC_BIOW(-1) & 0.916663 & 0.012444 & 73.66330 & 0.0000 \\
REC_MU & 0.238563 & 0.036551 & 6.526858 & 0.0000 \\
\hline \hline Root MSE & 8.526593 & R-squared & 0.972816 \\
Mean dependent var & 53.36563 & Adjusted R-squared & 0.972716 \\
S.D. dependent var & 51.76258 & S.E. of regression & 8.550072 \\
Akaike info criterion & 7.135226 & Sum squared resid & 39768.43 \\
Schwarz criterion & 7.158833 & Log likelihood & -1948.484 \\
Hannan-Quinn criter. & 7.144453 & F-statistic & 9733.870 \\
Durbin-Watson stat & 2.206447 & Prob(F-statistic) & 0.000000 \\
: & & & \\
\hline
\end{tabular}

Figure 3. Formation of equation (2): panel least squares revision method.

The application of the method shows that the adjusted $R$ squared is 0.97 . The statistical validity is revised by applying the Lagrange multiplier tests. The tests show the correct statistical validity. The probability for the Breausch-Pagan test is lower than 0.05. The detailed presentation of tests is presented in Appendix C.

\section{Discussion}

The returns management process deals with product returns from customers. These activities should be fast, controllable, visible and straightforward. Repeated returns can 
also occur when the seller rejects the return and returns it to the buyer without a refund. A type of reverse logistics for packaging management aims to reuse packaging materials to reduce waste and recycle. In the article, the returns management process is considered as relating primarily to the avoidance of returns and the return of products from customers. Redemption actions should be quick, simple, visible and easy to use. It is also possible that custom-made items will be returned if the seller refuses to accept the buyer's return and sends the item back to the buyer. Another type of reverse logistics discussed in the article aims to reuse packaging materials to reduce waste and recycle. Also described other types of reverse logistics management for product repair, refurbishment, and rework, including refurbishment, remanufacturing, and reconditioning activities. Repairs include the disassembly, cleaning, and reassembly of products.

To achieve sustainable development, the authors point out the need to build and expand a sustainable network in all supply chain processes, i.e., production, logistics and reverse logistics. Furthermore, particularly sustainable development aims to draw attention to an integrated approach to ecological, social and economic aspects, which leads to long term, sustainable profit growth.

The development of sustainable reverse logistics and sustainable waste management is essential for environmental protection. By reducing the overall negative impact of logistics on the environment, sustainable return logistics aims to solve environmental problems while considering the costs of recycling and disposing of waste, especially municipal waste. Therefore, the article discusses sustainable practices such as recycling, reuse, waste reduction, product return management, etc., to achieve process efficiency.

The study has some limitations: the authors do not revise the process efficiency; they identify the options for how to increase recycling rates and provide the dynamic regression model, which proves that.

\section{Conclusions}

The links and interdependencies between municipal waste and reverse logistics are a new topic that other authors have not explored so far. This article reveals that municipal waste is strongly and directly related to reverse logistics processes. The paper also discusses essential elements of reverse logistics and municipal solid waste. The authors constructed the hierarchy of qualitative methods and models for researching reverse logistics and waste collection aspects and figure out that most often authors apply mixed-integer linear programming method.

The authors identified aspects of materials and their recyclability opportunities. Also, highlighted reverse logistics, which is playing an important role in seeking sustainable development. The authors provided a methodology that identifies connection points between municipal waste and reverse logistics. Reverse logistics appear as supporting production processes and the collection of municipal waste from end-users. The authors identified three levels of connection points. The second level of methodology was researched in a mathematical way seeking to identify interconnections between recycling and municipal waste generation. The authors determined that the link among the above-identified components is positive.

Further research directions could evaluate the impact of specific materials and production methods on improving recycling rates. The study could be also extended to other countries and the recycling of other waste streams could be added. Also, the authors could compare the flows of reverse logistics with forwarding logistics.

Author Contributions: Conceptualisation is delivered by O.L. and A.B.; writing-original draft preparation is made by O.L.; writing-reviewing and editing are given by V.D., and methodology is constructed by A.B. All authors have read and agreed to the published version of the manuscript.

Funding: This research received no external funding.

Institutional Review Board Statement: Not applicable. 
Informed Consent Statement: Not applicable.

Data Availability Statement: Not applicable.

Conflicts of Interest: The authors declare no conflict of interest.

\section{Appendix A}
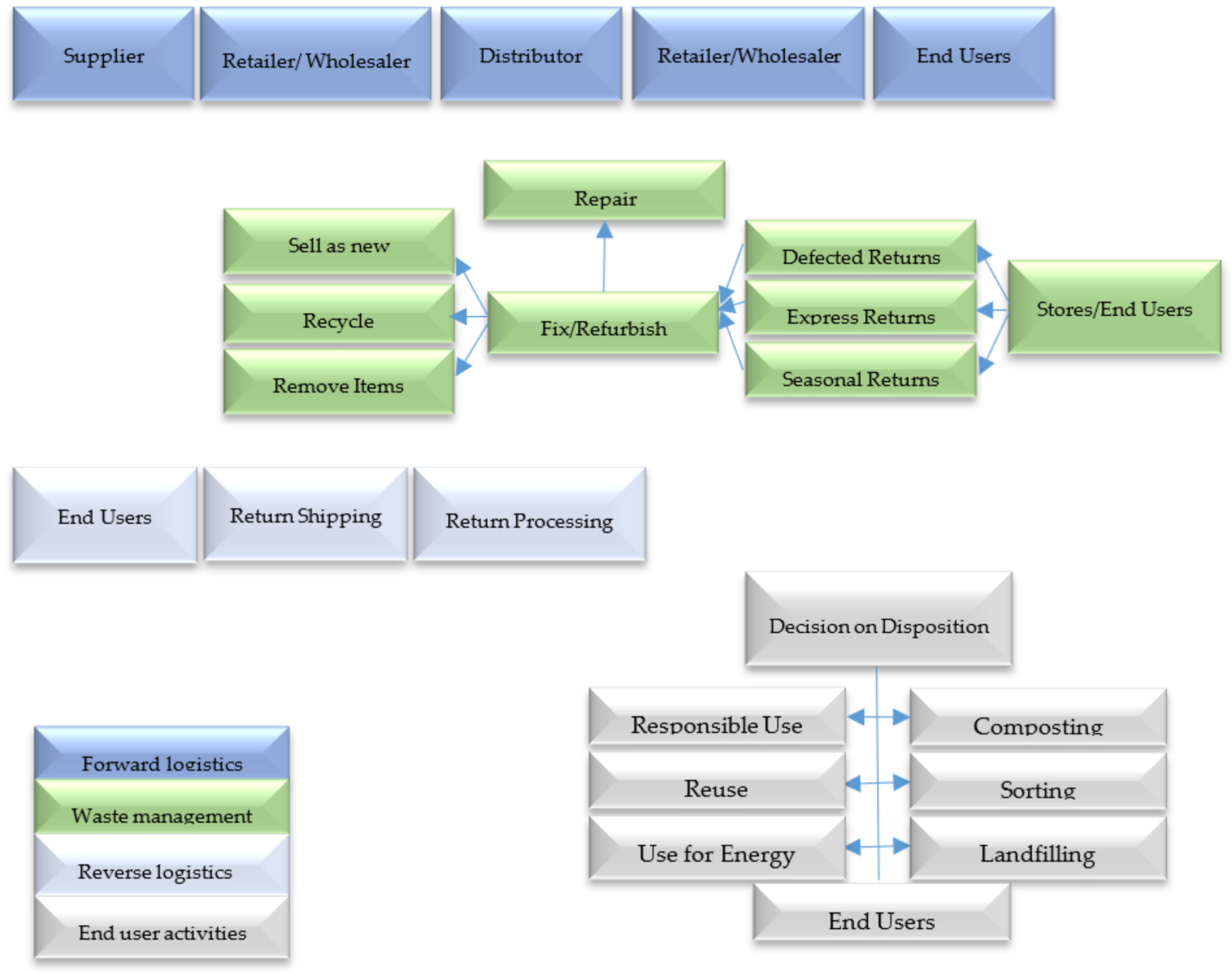

Figure A1. Reliance on reverse logistics and waste management.

\section{Appendix B}

Table A1. The abbreviations and definitions of key terms in the paper.

\begin{tabular}{ccl}
\hline Full name & Abbreviation & \multicolumn{1}{c}{ Definition } \\
\hline Reverse logistics & RL & $\begin{array}{l}\text { Reverse logistics (RL) is the process of planning, implementing, and controlling the } \\
\text { efficient and cost-effective flow of raw materials, in-process inventory, finished } \\
\text { goods, and related information from the point of consumption to the point of } \\
\text { origin to recapture value or proper disposal [9]. }\end{array}$ \\
Municipal solid waste & MSW & $\begin{array}{l}\text { MSW is defined to include refuse from households, non-hazardous solid waste } \\
\text { from industrial, commercial and institutional establishments (including hospitals), } \\
\text { market waste, yard waste, and street sweepings [56]. }\end{array}$ \\
\hline
\end{tabular}




\section{Appendix C}

The authors performed Residual Cross-sectional dependence test:

Residual Cross-Section Dependence Test

Null hypothesis: No cross-section dependence (correlation) in residuals

Equation: EQ01_2VAR

Periods included: 19

Cross-sections included: 30

Total panel (unbalanced) observations: 547

Test employs centered correlations computed from pairwise samples

Test Statistic d.f. Prob.

\begin{tabular}{|c|c|c|}
\hline Breusch-Pagan LM & 615.87 & 435 \\
\hline Pesaran scaled LM & 6.13 & \\
\hline Bias-corrected scaled LM & 5.29 & \\
\hline Pesaran CD & -1.31 & \\
\hline
\end{tabular}

Figure A2. Residual Cross-sectional dependence test.

Figure A2 shows that Probability of Pesaran CD test is higher than 0.1. Also, the authors performed Redundant Fixed Effects tests:

Redundant Fixed Effects Tests

Equation: EQ01_2VAR

Test cross-section and period fixed effects

Effects Test

Cross-section $\mathrm{F}$

Cross-section Chi-square

Period F

Period Chi-square

Cross-Section/Period F

Cross-Section/Period Chi-square
Statistic d.f. Prob.

$\begin{array}{rrr}4.03 & -29497 & 0 \\ 115.64 & 29 & 0 \\ 1.40 & -18497 & 0.12 \\ 27.16 & 18 & 0.07 \\ 3.09 & -47497 & 0 \\ 140.34 & 47 & 0\end{array}$

Figure A3. Redundant Fixed Effects tests.

Figure A3 shows that Probability of Chow test is lower 0.05. Fix evaluation method is chosen properly.

\section{References}

1. Korhonen, J.; Koskivaara, A.; Toppinen, A. Riding a Trojan horse ? Future pathways of the fiber-based packaging industry in the bioeconomy. For. Policy Econ. 2020, 110, 101799. [CrossRef]

2. Boz, Z.; Korhonen, V.; Sand, C.K. Consumer Considerations for the Implementation of Sustainable Packaging: A Review. Sustainability 2020, 12, 2192. [CrossRef]

3. Hashmi, S.D.; Akram, S. Impact of green supply chain management on financial and environmental performance: Mediating role of operational performance and the moderating role of external pressures. LogForum 2021, 17, 359-371.

4. Modi, K.; Lowalekar, H.; Bhatta, N.M.K. Revolutionising supply chain management the theory of constraints way: A case study. Int. J. Prod. Res. 2019, 57, 3335-3361. [CrossRef] 
5. Afum, E.; Sun, B.Z.; Kusi, C.L.Y. Reverse Logistics, Stakeholder Influence and Supply Chain Performance in Ghanaian Manufacturing Sector. J. Supply Chain Manag. Syst. 2019, 8, 13-24.

6. Vargas, M.; Alfaro, M.; Karstegl, N.; Fuertes, G.; Gracia, M.D.; Mar-Ortiz, J.; Sabattin, J.; Duran, C.; Leal, N. Reverse logistics for solid waste from the construction industry. Adv. Civ. Eng. 2021, 2021, 6654718. [CrossRef]

7. Sarkis, J.; Helms, M.M.; Hervani, A.A. Reverse logistics and social sustainability. Corp. Soc. Responsib. Environ. Manag. 2010, 17, 337-354. [CrossRef]

8. Sepúlveda, J.M.; Banguera, L.; Fuertes, G.; Carrasco, R.; Vargas, M. Reverse and inverse logistic models for solid waste management. South Afr. J. Ind. Eng. 2017, 28, 120-132.

9. Lambert, S.; Riopel, D.; Abdul-Kader, W. A reverse logistics decisions conceptual framework. Comput. Ind. Eng. 2011, 61, 561-581. [CrossRef]

10. Mahajan, J.; Vakharia, A.J. Waste Management: A Reverse Supply Chain Perspective. Vikalpa 2016, 41, 197-208. [CrossRef]

11. De Brito, M.P.; Dekker, R.; Flapper, S.D.P. Reverse logistics: A review of case studies. Distrib. Logist. 2005, $243-281$.

12. Turki, S.; Sauvey, C.; Rezg, N. Modelling and optimization of a manufacturing/remanufacturing system with storage facility under carbon cap and trade policy. J. Clean. Prod. 2018, 193, 441-458. [CrossRef]

13. Trochu, J.; Chaabane, A.; Ouhimmou, M. Reverse logistics network redesign under uncertainty for wood waste in the CRD industry. Resour. Conserv. Recycl. 2018, 128, 32-47. [CrossRef]

14. Mesjasz-Lech, A. Reverse logistics of municipal solid waste-Towards zero waste cities. Transp. Res. Procedia. 2019, 39, 320-332. [CrossRef]

15. Jalil, E.E.A.; Grant, D.B.; Nicholson, J.D.; Deutz, P. Reverse logistics in household recycling and waste systems: A symbiosis perspective. Supply Chain Manag. 2016, 21, 245-258. [CrossRef]

16. Alamerew, Y.A.; Brissaud, D. Modelling reverse supply chain through system dynamics for realising the transition towards the circular economy: A case study on electric vehicle batteries. J. Clean. Prod. 2020, 254, 120025. [CrossRef]

17. Valenzuela, J.; Alfaro, M.; Fuertes, G.; Vargas, M.; Sáez-Navarrete, C. Reverse logistics models for the collection of plastic waste: A literature review. Waste Manag. Res. 2021, 39, 1116-1134. [CrossRef]

18. Agrawal, S.; Singh, R.K.; Murtaza, Q. A literature review and perspectives in reverse logistics. Resour. Conserv. Recycl. 2015, 97, 76-92. [CrossRef]

19. Senthil, S.; Srirangacharyulu, B.; Ramesh, A. A robust hybrid multi-criteria decision making methodology for contractor evaluation and selection in third-party reverse logistics. Expert Syst. Appl. 2014, 41, 50-58. [CrossRef]

20. De Oliveira, U.R.; Espindola, L.S.; da Silva, I.R.; da Silva, I.N.; Rocha, H.M. A systematic literature review on green supply chain management: Research implications and future perspectives. J. Clean. Prod. 2018, 187, 537-561. [CrossRef]

21. Lai, K.H.; Wu, S.J.; Wong, C.W. Did reverse logistics practices hit the triple bottom line of Chinese manufacturers? Int. J. Prod. Econ. 2013, 146, 106-117. [CrossRef]

22. Çankaya, S.Y.; Sezen, B. Effects of green supply chain management practices on sustainability performance. J. Manuf. Technol. Manag. 2019, 30, 98-121. [CrossRef]

23. Bouzon, M.; Govindan, K.; Rodriguez, C.M.T. Evaluating barriers for reverse logistics implementation under a multiple stakeholders' perspective analysis using grey decision making approach. Resour. Conserv. Recycl. 2018, 128, 315-335. [CrossRef]

24. Govindan, K.; Bouzon, M. From a literature review to a multi-perspective framework for reverse logistics barriers and drivers. $J$. Clean. Prod. 2018, 187, 318-337. [CrossRef]

25. Sirisawat, P.; Kiatcharoenpol, T. Fuzzy AHP-TOPSIS approaches to prioritizing solutions for reverse logistics barriers. Comput. Ind. Eng. 2018, 117, 303-318. [CrossRef]

26. Amemba, C.S. Green supply chain best practices in hospitality industry in Kenya. Glob. J. Commer. Manag. Perspect. 2013, 2, 7-18.

27. Sharma, V.K.; Chandna, P.; Bhardwaj, A. Green supply chain management related performance indicators in agro industry: A review. J. Clean. Prod. 2017, 141, 1194-1208. [CrossRef]

28. Wijewickrama, M.K.C.S.; Chileshe, N.; Rameezdeen, R.; Ochoa, J.J. Information sharing in reverse logistics supply chain of demolition waste: A systematic literature review. J. Clean. Prod. 2021, 280, 124359. [CrossRef]

29. Lim, M.K.; Tseng, M.L.; Tan, K.H.; Bui, T.D. Knowledge management in sustainable supply chain management: Improving performance through an interpretive structural modelling approach. J. Clean. Prod. 2017, 162, 806-816. [CrossRef]

30. Lee, C.K.M.; Lam, J.S.L. Managing reverse logistics to enhance sustainability of industrial marketing. Ind. Mark. Manag. 2012, 41, 589-598. [CrossRef]

31. Schamne, A.N.; Nagalli, A. Reverse logistics in the construction sector: A literature review. Electron. J. Geotech. Eng. 2016, 21, 691-702.

32. Liao, T.Y. Reverse logistics network design for product recovery and remanufacturing. Appl. Math. Model. 2018, 60, 145-163. [CrossRef]

33. Hao, H.; Sun, Y.; Mei, X.; Zhou, Y. Reverse Logistics Network Design of Electric Vehicle Batteries considering Recall Risk. Math. Probl. Eng. 2021, 2021, 5518049. [CrossRef]

34. Huscroft, J.R.; Hazen, B.T.; Hall, D.J.; Skipper, J.B.; Hanna, J.B. Reverse logistics: Past research, current management issues, and future directions. Int. J. Logist. Manag. 2013, 24, 304-327. [CrossRef]

35. Beh, L.S.; Ghobadian, A.; He, Q.; Gallear, D.; O’Regan, N. Second-life retailing: A reverse supply chain perspective. Supply Chain. Manag. Int. J. 2016, 21, 259-272. [CrossRef] 
36. Chen, L.; Duan, D.; Mishra, A.R.; Alrasheedi, M. Sustainable third-party reverse logistics provider selection to promote circular economy using new uncertain interval-valued intuitionistic fuzzy-projection model. J. Enterp. Inf. Manag. 2021, 34-48. [CrossRef]

37. Magazzino, C.; Alola, A.A.; Schneider, N. The trilemma of innovation, logistics performance, and environmental quality in 25 topmost logistics countries: A quantile regression evidence. J. Clean. Prod. 2021, 322, 129050. [CrossRef]

38. Aguezzoul, A. Third-party logistics selection problem: A literature review on criteria and methods. Omega 2014, 49, 69-78. [CrossRef]

39. Li, Y.L.; Ying, C.S.; Chin, K.S.; Yang, H.T.; Xu, J. Third-party reverse logistics provider selection approach based on hybridinformation MCDM and cumulative prospect theory. J. Clean. Prod. 2018, 195, 573-584. [CrossRef]

40. Kurdve, M.; Shahbazi, S.; Wendin, M.; Bengtsson, C.; Wiktorsson, M. Waste flow mapping to improve sustainability of waste management: A case study approach. J. Clean. Prod. 2015, 98, 304-315. [CrossRef]

41. Da Silveira Guimarães, J.L.; Salomon, V.A.P. ANP applied to the evaluation of performance indicators of reverse logistics in footwear industry. Procedia Comput. Sci. 2015, 55, 139-148. [CrossRef]

42. Sangwan, K.S. Key activities, decision variables and performance indicators of reverse logistics. Procedia Cirp. 2017, 61, 257-262. [CrossRef]

43. Abdulrahman, M.D.; Gunasekaran, A.; Subramanian, N. Critical barriers in implementing reverse logistics in the Chinese manufacturing sectors. Int. J. Prod. Econ. 2014, 147, 460-471. [CrossRef]

44. Bai, C.; Sarkis, J. Flexibility in reverse logistics: A framework and evaluation approach. J. Clean. Prod. 2013, 47, 306-318. [CrossRef]

45. Hsu, C.C.; Tan, K.C.; Zailani, S.H.M. Strategic orientations, sustainable supply chain initiatives, and reverse logistics: Empirical evidence from an emerging market. Int. J. Oper. Prod. Manag. 2016, 36, 86-110. [CrossRef]

46. Dubey, R.; Gunasekaran, A.; Papadopoulos, T.; Childe, S.J.; Shibin, K.T.; Wamba, S.F. Sustainable supply chain management: Framework and further research directions. J. Clean. Prod. 2017, 142, 1119-1130. [CrossRef]

47. Căilean, D.; Teodosiu, C. An assessment of the Romanian solid waste management system based on sustainable development indicators. Sustain. Prod. Consum. 2016, 8, 45-56. [CrossRef]

48. Govindan, K.; Palaniappan, M.; Zhu, Q.; Kannan, D. Analysis of third party reverse logistics provider using interpretive structural modeling. Int. J. Prod. Econ. 2012, 140, 204-211. [CrossRef]

49. Bernon, M.; Rossi, S.; Cullen, J. Retail reverse logistics: A call and grounding framework for research. Int. J. Phys. Distrib. Logist. Manag. 2011, 41, 484-510. [CrossRef]

50. Govindan, K.; Soleimani, H.; Kannan, D. Reverse logistics and closed-loop supply chain: A comprehensive review to explore the future. Eur. J. Oper. Res. 2015, 240, 603-626. [CrossRef]

51. Sarkis, J.; Zhu, Q. Environmental sustainability and production: Taking the road less travelled. Int. J. Prod. Res. 2018, 56, 743-759. [CrossRef]

52. Vanalle, R.M.; Ganga, G.M.D.; Godinho Filho, M.; Lucato, W.C. Green supply chain management: An investigation of pressures, practices, and performance within the Brazilian automotive supply chain. J. Clean. Prod. 2017, 151, 250-259. [CrossRef]

53. Andronie, M.; Lăzăroiu, G.; Ștefănescu, R.; Uță, C.; Dijmărescu, I. Sustainable, Smart, and Sensing Technologies for Cyber-Physical Manufacturing Systems: A Systematic Literature Review. Sustainability 2021, 13, 5495. [CrossRef]

54. Jabbour, C.J.C.; de Sousa Jabbour, A.B.L. Green human resource management and green supply chain management: Linking two emerging agendas. J. Clean. Prod. 2016, 112, 1824-1833. [CrossRef]

55. Rebai, N.; Benabdelhafid, A.; Benaissa, M. A Decision Support System Proposal in a reverse logistic environment. In Proceedings of the 4th International Conference on Logistics, Hammamet, Tunisia, 31 May-3 June 2011; pp. 424-429.

56. Ogwueleka, T. Municipal solid waste characteristics and management in Nigeria. J. Environ. Health Sci. Eng. 2009, 6, 173-180.

57. Vergara, S.E.; Tchobanoglous, G. Municipal solid waste and the environment: A global perspective. Annu. Rev. Environ. Resour. 2012, 37, 277-309. [CrossRef]

58. Babatunde, B.B.; Vincent-Akpu, I.F.; Woke, G.N.; Atarhinyo, E.; Aharanwa, U.C.; Green, A.F.; Isaac-Joe, O. Comparative analysis of municipal solid waste (MSW) composition in three local government areas in Rivers State, Nigeria. Afr. J. Environ. Sci. Technol. 2013, 7, 874-881.

59. Dyczkowska, J.; Bulhakova, Y.; Łukaszczyk, Z.; Maryniak, A. Waste Management as an Element of the Creation of a Closed Loop of Supply Chains on the Example of Mining and Extractive Industry. Manag. Syst. Prod. Eng. 2020, 28, 60-69. [CrossRef]

60. Hennebert, P.; Van der Sloot, H.A.; Rebischung, F.; Weltens, R.; Geerts, L.; Hjelmar, O. Hazard property classification of waste according to the recent propositions of the EC using different methods. Waste Manag. 2014, 34, 1739-1751. [CrossRef]

61. Sztangret, I.B. The marketing value creation in the waste management sector-multi-conceptual business model. SHS Web Conf. 2020, 73, 01028. [CrossRef]

62. Beullens, P. Reverse logistics in effective recovery of products from waste materials. Rev. Environ. Sci. Bio/Technol. 2004, 3, 283-306. [CrossRef]

63. Matar, N.; Jaber, M.Y.; Searcy, C. A reverse logistics inventory model for plastic bottles. Int. J. Logist. Manag. 2014, 25, 315-333. [CrossRef]

64. Bazan, E.; Jaber, M.Y.; El Saadany, A.M. Carbon emissions and energy effects on manufacturing-remanufacturing inventory models. Comput. Ind. Eng. 2015, 88, 307-316. [CrossRef]

65. Ferri, G.L.; Chaves, G.D.L.D.; Ribeiro, G.M. Reverse logistics network for municipal solid waste management: The inclusion of waste pickers as a Brazilian legal requirement. Waste Manag. 2015, 40, 173-191. [CrossRef] 
66. Choudhary, A.; Sarkar, S.; Settur, S.; Tiwari, M.K. A carbon market sensitive optimization model for integrated forward-reverse logistics. Int. J. Prod. Econ. 2015, 164, 433-444. [CrossRef]

67. Shi, L.H. A mixed integer linear programming for medical waste reverse logistics network design. In Proceedings of the International Conference on Management Science and Engineering, Moscow, Russia, 14-16 September 2009; pp. 1971-1975.

68. Gomes, M.I.; Barbosa-Povoa, A.P.; Novais, A.Q. Modelling a recovery network for WEEE: A case study in Portugal. Waste Manag. 2011, 31, 1645-1660. [CrossRef] [PubMed]

69. Siri, S.; Mendis, I.T.; Repetto, C. The facility location problem in a reverse logistic network: Weeenmodels project in the city of Genoa. In Proceedings of the 18th International Conference on Intelligent Transportation Systems, Gran Canaria, Spain, 15-18 September 2015; pp. 1581-1586.

70. Capraz, O.; Polat, O.; Gungor, A. Planning of waste electrical and electronic equipment (WEEE) recycling facilities: MILP modelling and case study investigation. Flex. Serv. Manuf. J. 2015, 27, 479-508. [CrossRef]

71. Kilic, H.S.; Cebeci, U.; Ayhan, M.B. Reverse logistics system design for the waste of electrical and electronic equipment (WEEE) in Turkey. Resour. Conserv. Recycl. 2015, 95, 120-132. [CrossRef]

72. Demirel, E.; Demirel, N.; Gökçen, H. A mixed integer linear programming model to optimize reverse logistics activities of end-of-life vehicles in Turkey. J. Clean. Prod. 2016, 112, 2101-2113. [CrossRef]

73. Tang, J.; Liu, Y.; Fung, R.Y.; Luo, X. Industrial waste recycling strategies optimization problem: Mixed integer programming model and heuristics. Eng. Optim. 2008, 40, 1085-1100. [CrossRef]

74. Wang, I.L.; Yang, W.C. Fast heuristics for designing integrated e-waste reverse logistics networks. IEEE Trans. Electron. Packag. Manuf. 2007, 30, 147-154. [CrossRef]

75. Anne, M.; Nicholas, L.; Ithinji, G.K.; Bula, H.O. Reverse logistics practices and their effect on competitiveness of food manufacturing firms in Kenya. 2016. Available online: http://41.89.227.156:8080/xmlui/handle/123456789/524 (accessed on 10 December 2021).

76. Ho, G.T.S.; Choy, K.L.; Lam, C.H.Y.; Wong, D.W. Factors influencing implementation of reverse logistics: A survey among Hong Kong businesses. Meas. Bus. Excell. 2012, 16, 29-46. [CrossRef]

77. Khor, K.S.; Udin, Z.M.; Ramayah, T.; Hazen, B.T. Reverse logistics in Malaysia: The contingent role of institutional pressure. Int. J. Prod. Econ. 2016, 175, 96-108. [CrossRef]

78. Subulan, K.; Taşan, A.S.; Baykasoğlu, A. A fuzzy goal programming model to strategic planning problem of a lead/acid battery closed-loop supply chain. J. Manuf. Syst. 2015, 37, 243-264. [CrossRef]

79. Li, C.; Liu, F.; Cao, H.; Wang, Q. A stochastic dynamic programming based model for uncertain production planning of re-manufacturing system. Int. J. Prod. Res. 2009, 47, 3657-3668. [CrossRef]

80. Ahluwalia, P.K.; Nema, A.K. Multi-objective reverse logistics model for integrated computer waste management. Waste Manag. Res. 2006, 24, 514-527. [CrossRef] [PubMed]

81. Braga Marsola, K.; Leda Ramos de Oliveira, A.; Filassi, M.; Elias, A.A.; Andrade Rodrigues, F. Reverse logistics of empty pesticide containers: Solution or a problem? Int. J. Sustain. Eng. 2021, 14, 1451-1462. [CrossRef]

82. Bonev, M. Managing Reverse Logistics Using System Dynamics: A generic End-to-End Approach; Diplomica Verlag: Berlin, Germany, 2012.

83. Wang, L.; Goh, M.; Ding, R.; Mishra, V.K. Improved Simulated Annealing Based Network Model for E-Recycling Reverse Logistics Decisions under Uncertainty. Math. Probl. Eng. 2018, 2018, 4390480. [CrossRef]

84. Horvath, P.A.; Autry, C.W.; Wilcox, W.E. Liquidity implications of reverse logistics for retailers: A Markov chain approach. J. Retail. 2005, 81, 191-203. [CrossRef]

85. Hanafi, J.; Kara, S.; Kaebernick, H. Reverse logistics strategies for end-of-life products. Int. J. Logist. Manag. 2008, 19, 367-388. [CrossRef]

86. Mimouni, F.; Abouabdellah, A. Proposition of a modeling and an analysis methodology of integrated reverse logistics chain in the direct chain. J. Ind. Eng. Manag. 2016, 9, 359-373. [CrossRef]

87. Olugu, E.U.; Wong, K.Y. Fuzzy logic evaluation of reverse logistics performance in the automotive industry. Sci. Res. Essays 2011, $6,1639-1649$.

88. Huang, C.C.; Liang, W.Y.; Tseng, T.L.; Chen, P.H. The rough set based approach to generic routing problems: Case of reverse logistics supplier selection. J. Intell. Manuf. 2016, 27, 781-795. [CrossRef]

89. Bai, C.; Sarkis, J. Integrating and extending data and decision tools for sustainable third-party reverse logistics provider selection. Comput. Oper. Res. 2019, 110, 188-207. [CrossRef]

90. Hejrani, S.; Ko, H.S. A reverse logistics model for medical waste management. In IIE Annual Conference Proceedings; Institute of Industrial and Systems Engineers (IISE): Peachtree Corners, GA, USA, 2013; pp. 97-105.

91. Jin-feng, Z. The Application of the Multi-objective Evolutionary Algorithm in the Collection and Transportation System of Solid Waste. J. Guangdong Univ. Technol. 2011, 2, 51-64.

92. Cao, S.; Zhang, K. Optimization of the flow distribution of e-waste reverse logistics network based on NSGA II and TOPSIS. In Proceedings of the International Conference on E-Business and E-Government-(ICEE), Shanghai, China, 6-8 May 2011; pp. 1-5.

93. Lo, C.C.; Chen, H.M.; Huang, H.L. A multi-objective reverse logistics network for product returns. In Proceedings of the IEEE International Conference on Industrial Engineering and Engineering Management, Singapore, 8-11 December 2008; pp. 1634-1638. 
94. Lu, Y.; Li, X.; Liang, L. Multi-objective optimization of reverse logistics network based on improved particle swarm optimization. In Proceedings of the 7th World Congress on Intelligent Control and Automation, Chongqing, China, 25-27 June 2008; pp. 7476-7480.

95. Li, D.; Liu, C.; \& Li, K. A remanufacturing logistics network model based on improved multi-objective ant colony optimization. J. Eur. Des Systèmes Autom. 2019, 52, 391-395. [CrossRef]

96. Hsueh, J.T.; Lin, C.Y. Integrating the AHP and TOPSIS decision processes for evaluating the optimal collection strategy in reverse logistic for the TPI. Int. J. Green Energy 2017, 14, 1209-1220. [CrossRef]

97. Güzel, B.; Taş, A. Decision analysis on criteria that affect design of reverse logistic systems in textile sector. Tekstil ve Mühendis 2018, 25, 154-168. [CrossRef]

98. Zhou, Y.; Xu, L.; Muhammad Shaikh, G. Evaluating and prioritizing the green supply chain management practices in Pakistan: Based on delphi and fuzzy AHP approach. Symmetry 2019, 11, 1346. [CrossRef]

99. Hsueh, J.T.; Lin, C.Y. Constructing a network model to rank the optimal strategy for implementing the sorting process in reverse logistics: Case study of photovoltaic industry. Clean Technol. Environ. Policy 2015, 17, 155-174. [CrossRef]

100. Kumar, S.; Kumar, R. Forecasting of municipal solid waste generation using non-linear autoregressive (NAR) neural models. Waste Manag. 2021, 121, 206-214.

101. Gorji, M.A.; Jamali, M.B.; Iranpoor, M. A game-theoretic approach for decision analysis in end-of-life vehicle reverse supply chain regarding government subsidy. Waste Manag. 2021, 120, 734-747. [CrossRef] [PubMed]

102. Da Silva, T.R.; de Azevedo AR, G.; Cecchin, D.; Marvila, M.T.; Amran, M.; Fediuk, R.; Vatin, N.; Karelina, M.; Klyuev, S.; Szelag, M. Application of plastic wastes in construction materials: A review using the concept of life-cycle assessment in the context of recent research for future perspectives. Materials 2021, 14, 3549. [CrossRef] [PubMed]

103. Abdel-Shafy, H.I.; Mansour, M.S.M. Solid waste issue: Sources, composition, disposal, recycling, and valorisation. Egypt. J. Pet. 2018, 27, 1275-1290. [CrossRef]

104. Shi, K.; Zhou, Y.; Zhang, Z. Mapping the research trends of household waste recycling: A bibliometric analysis. Sustainability 2021, 13, 6029. [CrossRef]

105. Luo, Y.; Wu, L.; Huang, D.; Zhu, J. Household food waste in rural China: A noteworthy reality and a systematic analysis. Waste Manag. Res. 2021, 39, 1389-1395. [CrossRef]

106. Adelakun, G.I.; Adigun, A.I.; Niyi, A.S.B.; Tayo, O.J.O. An Assessment of the Effectiveness of the Waste Bins Collection and Disposal in Sango-Ota, Ogun. World Sci. News. 2019, 119, 27-40.

107. Pires, A.; Martinho, G. Waste hierarchy index for circular economy in waste management. Waste Manag. $2019,95,298-305$. [CrossRef]

108. Teigiserova, D.A.; Hamelin, L.; Thomsen, M. Towards transparent valorisation of food surplus, waste and loss: Clarifying definitions, food waste hierarchy, and role in the circular economy. Sci. Total Environ. 2020, 706, 136033. [CrossRef]

109. Alarcón, F.; Cortés-Pellicer, P.; Pérez-Perales, D.; Mengual-Recuerda, A. A reference model of reverse logistics process for improving sustainability in the supply chain. Sustainability 2021, 13, 10383. [CrossRef]

110. De Oliveira, U.R.; Aparecida Neto, L.; Abreu, P.A.F.; Fernandes, V.A. Risk management applied to the reverse logistics of solid waste. J. Clean. Prod. 2021, 296, 126517. [CrossRef]

111. Degenstein, L.M.; Mcqueen, R.H.; Krogman, N.T. What goes where ? Characterising Edmonton's municipal clothing waste stream and consumer clothing disposal. J. Clean. Prod. 2021, 296, 126516. [CrossRef]

112. Rehman, A.; Ali, K.; Hamid, T.; Nasir, H.; Ahmad, I. Effective Utilization of Municipal Solid Waste as Substitute for Natural Resources in Cement Industry. Civ. Eng. J. 2020, 6, 238-257. [CrossRef]

113. Tsai, W.T. Analysis of plastic waste reduction and recycling in Taiwan. Waste Manag. Res. 2021, 39, 713-719. [CrossRef]

114. Ghinea, C.; Drăgoi, E.N.; Comăniţă, E.D.; Gavrilescu, M.; Câmpean, T.; Curteanu, S.I.L.V.I.A.; Gavrilescu, M. Forecasting municipal solid waste generation using prognostic tools and regression analysis. J. Environ. Manag. 2016, 182, 80-93. [CrossRef] [PubMed]

115. Sofi, M.; Sabri, Y.; Zhou, Z.; Mendis, P. Transforming municipal solid waste into construction materials. Sustainability 2019, 11, 2661. [CrossRef]

116. Eurostat. 2021. Available online: https://ec.europa.eu/eurostat/statistics-explained/index.php?title=Municipal_waste_ statistics\#Municipal_waste_treatment (accessed on 8 August 2021).

117. Rimaitytè, I.; Ruzgas, T.; Denafas, G.; Račys, V.; Martuzevicius, D. Application and evaluation of forecasting methods for municipal solid waste generation in an eastern-European city. Waste Manag. Res. 2012, 30, 89-98. [CrossRef]

118. Purwani, A.; Hisjam, M.; Sutopo, W. Municipal solid waste logistics management: A study on reverse logistics. AIP Conf. Proc. 2020, 2217, 030181 .

119. Chung, S.S. Projecting municipal solid waste: The case of Hong Kong SAR. Resour. Conserv. Recycl. 2010, 54, 759-768. [CrossRef]

120. Smol, M.; Duda, J.; Czaplicka-Kotas, A.; Szołdrowska, D. Transformation towards circular economy (CE) in municipal waste management system: Model solutions for Poland. Sustainability 2020, 12, 4561. [CrossRef]

121. Vrabie, C. Converting municipal waste to energy through the biomass chain, a key technology for environmental issues in (Smart) cities. Sustainability 2021, 13, 4633. [CrossRef]

122. Vaida, D.; Lelea, D. Municipal Solid Waste Incineration: Recovery or Disposal. Case Study of City Timisoara, Romania. Procedia Eng. 2017, 181, 378-384. [CrossRef] 
123. Quina, M.J.; Bontempi, E.; Bogush, A.; Schlumberger, S.; Weibel, G.; Braga, R.; Funari, V.; Hyks, J.; Rasmussen, E.; Lederer, J. Technologies for the management of MSW incineration ashes from gas cleaning: New perspectives on recovery of secondary raw materials and circular economy. Sci. Total Environ. 2018, 635, 526-542. [CrossRef]

124. Rogers, D.S.; Tibben-lembke, R. An examination of reverse logistics practices. J. Bus. Logist. 2001, 22, 129-148. [CrossRef]

125. Stucki, M.; Jattke, M.; Berr, M.; Desing, H.; Green, A.; Hellweg, S.; Laurenti, R.; Meglin, R.; Muir, K.; Pedolin, D.; et al. How life cycle-based science and practice support the transition towards a sustainable economy. Int. J. Life Cycle Assess. 2021, 26, 1062-1069. [CrossRef]

126. Yu, H.; Dai, H.; Tian, G.; Wu, B.; Xie, Y.; Zhu, Y.; Zhang, T.; Fathollahi-Fard, A.M.; Tang, H. Key technology and application analysis of quick coding for recovery of retired energy vehicle battery. Renew. Sustain. Energy Rev. 2021, 135, 110129. [CrossRef]

127. Bernon, M.; Cullen, J. An integrated approach to managing reverse logistics. Int. J. Logist. Res. Appl. 2007, 10, 41-56. [CrossRef]

128. Visser, H.M.; Van Goor, A.R. Recycling and reverse logistics. Logist. Princ. Pract. 2020, 12, 371-390.

129. Kalpana, D.; Cho, S.H.; Lee, S.B.; Lee, Y.S.; Misra, R.; Renganathan, N.G. Recycled waste paper-A new source of raw material for electric double-layer capacitors. J. Power Sources. 2009, 190, 587-591. [CrossRef]

130. Erdenebold, U.; Choi, D.H.; Ho, K.S.; Cheol, K.G.; Wang, J.P. A study on reduction of copper smelting slag by carbon for recycling into metal values and cement raw material. Sustainability 2020, 12, 1421.

131. Guo, S.; Shen, B.; Choi, T.M.; Jung, S. A review on supply chain contracts in reverse logistics: Supply chain structures and channel leaderships. J. Clean. Prod. 2017, 144, 387-402. [CrossRef]

132. Walker, T.R.; McGuinty, E.; Charlebois, S.; Music, J. Single-use plastic packaging in the Canadian food industry: Consumer behavior and perceptions. Humanit. Soc. Sci. Commun. 2021, 8, 80. [CrossRef]

133. Reverberi, M. The new packaged food products containing insects as an ingredient. J. Insects as Food Feed. 2021, 7, 901-908. [CrossRef]

134. Wang, C.; Hoang, Q.; Nguyen, T. Integrating the EBM Model and LTS(A,A,A) Model to Evaluate the Efficiency in the Supply Chain of Packaging Industry in Vietnam. Axioms 2021, 10, 33. [CrossRef]

135. Pareek, V.; Khunteta, A. Pharmaceutical packaging: Current trends and future. Int. J. Pharm. Pharm. Sci. 2014, 6, 480-485.

136. Sundqvist-Andberg, H.; Åkerman, M. Sustainability governance and contested plastic food packaging-An integrative review. J. Clean. Prod. 2021, 306, 127111. [CrossRef]

137. Marangoni Júnior, L.; Cristianini, M.; Padula, M.; Anjos, C.A.R. Effect of high-pressure processing on characteristics of flexible packaging for foods and beverages. Food Res. Int. 2019, 119, 920-930. [CrossRef]

138. Dixon-Hardy, D.W.; Curran, B.A. Types of packaging waste from secondary sources (supermarkets) -The situation in the UK. Waste Manag. 2009, 29, 1198-1207. [CrossRef] [PubMed]

139. Gopinathar, P.; Prabha, G.; Ravichandran, K. The Role of Packaging in Manufacturing-A Brief Understanding. IOSR J. Bus. Manag. 2016, 18, 1-7.

140. Albaar, N.; Budiastra, I.W.; Hariyadi, Y. Influence of Secondary Packaging on Quality of Carrots During Transportation. Agric. Agric. Sci. Procedia. 2016, 9, 348-352. [CrossRef]

141. Mahmoudi, M.; Parviziomran, I. Reusable packaging in supply chains: A review of environmental and economic impacts, logistics system designs, and operations management. Int. J. Prod. Econ. 2020, 228, 107730. [CrossRef]

142. Rana, S.; Siddiqui, S.; Goyal, A. Extension of the shelf life of guava by individual packaging with cling and shrink films. J. Food Sci. Technol. 2015, 52, 8148-8155. [CrossRef]

143. Van Esch, P.; Heller, J.; Northey, G. The effects of inner packaging color on the desirability of food. J. Retail. Consum. Serv. 2019, 50, 94-102. [CrossRef]

144. Sutrisna, A.; Vossenaar, M.; Poonawala, A.; Mallipu, A.; Izwardy, D.; Menon, R.; Tumilowicz, A. Improved information and educational messages on outer packaging of micronutrient powders distributed in Indonesia increase caregiver knowledge and adherence to recommended use. Nutrients 2018, 10, 747. [CrossRef] [PubMed]

145. Zhang, R.; Ma, X.; Shen, X.; Zhai, Y.; Zhang, T.; Ji, C.; Hong, J. PET bottles recycling in China: An LCA coupled with LCC case study of blanket production made of waste PET bottles. J. Environ. Manage. 2020, 260, 110062. [CrossRef] [PubMed]

146. Han, J.; Gu, L.Y.; Chen, D.R. Application of Innovative Design Thinking in Product Design* Intelligent Waste Paper Recycling Machine Design Case. E3S Web Conf. 2021, 236, 04062. [CrossRef]

147. Greenwood, S.C.; Walker, S.; Baird, H.M.; Parsons, R.; Mehl, S.; Webb, T.L.; Slark, A.T.; Ryan, A.J.; Rothman, R.H. Many Happy Returns: Combining insights from the environmental and behavioural sciences to understand what is required to make reusable packaging mainstream. Sustain. Prod. Consum. 2021, 27, 1688-1702. [CrossRef]

148. Joseph, B.; James, J.; Kalarikkal, N.; Thomas, S. Recycling of medical plastics. Adv. Ind. Eng. Polym. Res. 2021, 4, 199-208. [CrossRef]

149. Sasaki, Y.; Orikasa, T.; Nakamura, N.; Hayashi, K.; Yasaka, Y.; Makino, N.; Shobatake, K.; Koide, S.; Shiina, T. Optimal packaging for strawberry transportation: Evaluation and modeling of the relationship between food loss reduction and environmental impact. J. Food Eng. 2021, 314, 110767. [CrossRef]

150. Petris, G.; Petrone, S.; Campagnoli, P. Dynamic linear models. In Dynamic Linear Models with R; Springer: New York, NY, USA, 2009; pp. 31-84. 